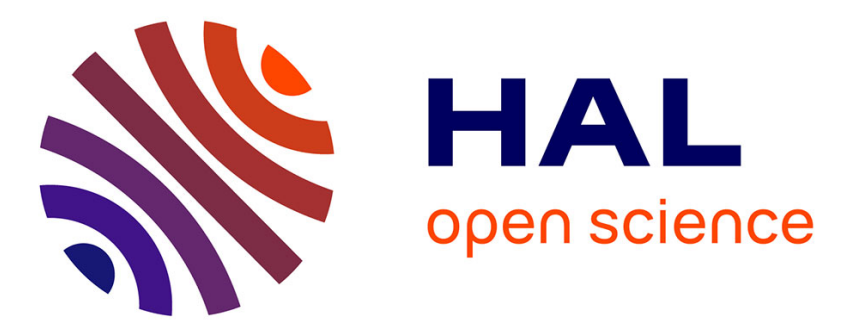

\title{
Co-seismic and cumulative offsets of the recent earthquakes along the Karakax left-lateral strike-slip fault in western Tibet
}

Haibing Li, Jerome van Der Woerd, Zhiming Sun, Jialiang Si, Paul Tapponnier, Jiawei Pan, Dongliang Liu, Marie-Luce Chevalier

\section{To cite this version:}

Haibing Li, Jerome van Der Woerd, Zhiming Sun, Jialiang Si, Paul Tapponnier, et al.. Co-seismic and cumulative offsets of the recent earthquakes along the Karakax left-lateral strike-slip fault in western Tibet. Gondwana Research, 2011, 21, pp.64-87. 10.1016/j.gr.2011.07.025 . hal-00683742

\section{HAL Id: hal-00683742 https://hal.science/hal-00683742}

Submitted on 29 Mar 2012

HAL is a multi-disciplinary open access archive for the deposit and dissemination of scientific research documents, whether they are published or not. The documents may come from teaching and research institutions in France or abroad, or from public or private research centers.
L'archive ouverte pluridisciplinaire HAL, est destinée au dépôt et à la diffusion de documents scientifiques de niveau recherche, publiés ou non, émanant des établissements d'enseignement et de recherche français ou étrangers, des laboratoires publics ou privés. 


\title{
Co-seismic and cumulative offsets of the recent earthquakes along the Karakax left-lateral strike-slip fault in western Tibet
}

\author{
Haibing Li ${ }^{\text {a,b,* }}$, Jérôme Van der Woerd ${ }^{\mathrm{c}}$, Zhiming Sun ${ }^{\mathrm{d}}$, Jialiang Si ${ }^{\mathrm{a}, \mathrm{b}}$, \\ Paul Tapponnier, ${ }^{\mathrm{ef}}$, Jiawei Pan ${ }^{\mathrm{a}, \mathrm{b}}$, Dongliang Liu ${ }^{\mathrm{a}, \mathrm{b}}$, Marie-Luce Chevalier ${ }^{\mathrm{a}, \mathrm{b}}$
}

\begin{abstract}
${ }^{\text {a }}$ State Key Laboratory of Continental Tectonic and Dynamics
${ }^{\mathrm{b}}$ Institute of Geology, Chinese Academy of Geological Sciences, Beijing 100037, P.R. China

${ }^{\mathrm{c}}$ Institut de Physique du Globe de Strasbourg, 67084, Strasbourg, France

${ }^{\mathrm{d}}$ Institute of Geomechanics, Chinese Academy of Geological Sciences, Beijing 100081, P.R. China

${ }^{\mathrm{e}}$ Earth Observatory of Singapore, Nanyang Technological University, Singapore

${ }^{\mathrm{f}}$ Institut de Physique du Globe de Paris, 75005 Paris, France
\end{abstract}

* Corresponding author. Institute of Geology, Chinese Academy of Geological

Sciences,

No.26, Baiwanzhuang Road, Beijing 100037, China. Tel.: +86 10 68990581; fax: +86

1068994781.

E-mail: lihaibing06@yahoo.com.cn (H. Li). 


\section{Abstract}

The $400 \mathrm{~km}$-long Karakax left-lateral strike-slip fault is the westernmost segment of the Altyn Tagh fault. It separates northwestern Tibet to the south from the Tarim basin to the north. The western section of the Karakax fault exhibits clear co-seismic surface ruptures of past large earthquakes. Geomorphic offset measurements from the field and high-resolution Ikonos images along $1.5 \mathrm{~km}$ across the Sanshiliyingfang fan and along $55 \mathrm{~km}$ of the fault, range from 3 to $28 \mathrm{~m}$, with distinct clusters at $6 \pm 2(3), 14 \pm 2,19 \pm 2$ and $24 \pm 3 \mathrm{~m}$. The cluster of the smallest offsets around $6 \mathrm{~m}$ (full range from 3 to $10 \mathrm{~m}$ ) distributed over a minimum length of $55 \mathrm{~km}$, is attributed to the last largest surface rupturing event that testifies of the occurrence of a magnitude Mw 7.4-7.6 earthquake along the Karakax fault. We interpret the other offset clusters as the possible repetition of similarly sized events thus favoring a characteristic slip model for the Karakax fault. In a $3 \mathrm{~m}$-deep trench dug across the active trace of the fault we can identify the main rupture strands of the last and penultimate events. The penultimate event horizon, a silty-sand layer, has been radiocarbon dated at $975-1020$ A.D. (AMS ${ }^{14} \mathrm{C}$ age). It is proposed that large Mw 7.4-7.6 events with co-seismic slip of about $6 \mathrm{~m}$ rupture the Karakax fault with a return time of about 900 years implying an average slip-rate of about $6-7 \mathrm{~mm} / \mathrm{yr}$ during the late Holocene. These results suggest that the Karakax fault is the largest left-lateral strike-slip fault at the rim of northwestern Tibet accommodating eastward movement of Tibet due to the India-Eurasia collision. 
Keywords: Altyn Tagh fault, Karakax fault, co-seismic offset, earthquake recurrence time, characteristic slip, Tibetan plateau

\section{Introduction}

How earthquakes repeat in space and time along an active fault is key to unravel its seismic behavior and has strong implications on hazard assessment. Despite the paucity of long enough earthquake time series, several conceptual models of the seismic cycle have been proposed. The seismic cycle is usually described as the succession of an inter-seismic phase, the time between two events, and a co-seismic phase when the seismic event occurs followed by a return to the inter-seismic phase. Most models more or less propose that a seismic event occurs after a certain amount of stress has accumulated on the fault plane, reaching a threshold triggering slip on the fault. For instance, if stress accumulates continuously at a constant rate due to constant far field motion of the blocks separated by the fault, usually measured as the average long-term slip-rate, and depending on either stress drop or stress threshold, one can define time-predictable or slip-predictable behaviors, also called characteristic-earthquake or characteristic-slip models, respectively, while a combination of both is also possible (e.g. Schwartz and Coppersmith, 1984; Sieh, 1996). In general, historical or instrumental records are short when compared to the return time of large strike-slip earthquakes (e.g. Peltzer et al., 1988; Zhang et al., 1988; Lasserre et al., 1999; Washburn et al., 2001; Liu-Zeng et al., 2007), thus the evidence for characteristic behavior along faults is rarely inferred from direct 
measurements, but is mostly deduced from geological analysis of dated faulted sediments or offset geomorphic features (e.g. Sieh, 1996; Lasserre et al., 1999; Tapponnier et al., 2001a; Van der Woerd et al., 2002; Liu-Zeng et al., 2004; Li et al., 2005).

The repetition of earthquakes on a localized fault plane has been widely used in trenching studies to recover the timing of past major events along strike-slip faults (e.g. Sieh, 1984; Fumal et al., 1993; Weldon et al., 2004; Daeron et al., 2007). More sophisticated studies have tried to link a displacement measurement to the time series (e.g. 3 dimensional trenching, Liu-Zeng et al., 2004, 2006). The difficulty, however, to fully describe the size and extent of past earthquake ruptures only by trenching (e.g. Weldon et al., 2004) has emphasized the need to map the spatial extent of present and past surface ruptures traces from geomorphic offsets analyzed in the field, from remote sensing imagery (air photos or high-resolution satellite images) or topography (e.g. Armijo et al., 1989; Klinger et al., 2005; Zielke et al., 2010; Klinger et al., 2011). The use of satellite imagery to document offsets along faults has been extensively applied along the active strike-slip faults of Tibet (Tapponnier and Molnar, 1977; Peltzer et al., 1988, 1989; Armijo et al., 1989; Liu, 1993; Zhang et al., 1995; Meyer et al., 1998; Van der Woerd et al., 2002; Mériaux et al., 2004, 2005) and elsewhere (e.g. Ritz et al., 1995; Hubert-Ferrari et al., 2002). Limited by the resolution of the images (10 and $30 \mathrm{~m}$, for SPOT and Landsat images, respectively), these studies were not aimed at describing past ruptures. The recent availability of high-resolution imagery (0.6 to $1 \mathrm{~m}$, for Quickbird or Ikonos images, respectively) makes possible the 
description of sub-metric to several meters long offsets, typical of large magnitude 7 to 8 events, specially in remote areas where field access is uneasy (e.g. Li et al., 2005; Klinger et al., 2005, 2011).

The Altyn Tagh fault (ATF) is one of the major strike-slip faults in the Tibetan Plateau, and it has played an important role in the eastward extrusion of the Tibetan Plateau and accommodate the ongoing northward penetration of the Indian plate into the Eurasian plate (e.g. Molnar and Tapponnier, 1975; Tapponnier and Molnar, 1977; Avouac and Tapponnier, 1993; Meyer et al., 1998; Li et al., 2006). In this paper, we take advantage of well preserved geomorphic offsets along a stretch of the ATF to better document its seismic behavior and the occurrence of past large earthquakes. This is particularly appropriate for the ATF as the quantitative description of past large events along its entire length is rather poor. While the ATF is a major player in the present kinematics of the collision (Molnar and Tapponnier, 1975; Tapponnier and Molnar, 1977; Avouac and Tapponnier, 1993; Tapponnier et al., 2001b; Yin et al., 2002), its long-term slip-rate is subject of controversy (e.g. Mériaux et al., 2004; Wallace et al., 2004; Cowgill, 2007; Gold et al., 2011) and its seismic behavior remains poorly documented (e.g. Molnar et al., 1987; Ge et al., 1992; Xu and Deng, 1996; Washburn et al., 2001).

While the central and eastern segments of the ATF have been mostly targeted in recent works, we studied a $60 \mathrm{~km}$ long stretch of the Karakax fault, the westernmost segment of the ATF in western Tibet (Tapponnier and Molnar, 1977; Peltzer et al., 1989; Avouac, 1991; Ge et al., 1992). We will first describe how we make use of 
high-resolution images and field observations to reconstruct the recent slip history along the fault and then discuss the seismic behavior of the ATF and the tectonic implications of our results.

\section{Tectonic setting of the Karakax fault}

The Altyn Tagh left-lateral strike-slip fault marks the boundary between the Tibetan plateau to the south and the Tarim basin to the north between $77^{\circ} \mathrm{E}$ and $97^{\circ} \mathrm{E}$ over a length of $\sim 2000 \mathrm{~km}$ (Tapponnier and Molnar, 1977; Ge et al., 1992; Yin et al., 2002; Fig. 1a). The major role of the ATF in the India-Eurasia collision is illustrated by the about $500 \mathrm{~km}$ left-slip it has accommodated since the Oligo-Miocene (Peltzer and Tapponnier, 1988; Meyer et al., 1998; Yue and Liou, 1999; Tapponnier et al., 2001b; Cowgill et al., 2003; Yue et al., 2005) and by its centimetric slip-rate (Bendick et al., 2000; Mériaux et al., 2004, 2005; Cowgill et al., 2009; Gold et al., 2011; Loveless and Meade, 2011).

The ATF can be divided in 3 main segments, western, central and eastern segments, based on major geometrical properties of the fault zone (Fig. 1; Tapponnier and Molnar, 1977; Peltzer et al., 1989; Mériaux et al., 2005). The central section strikes $\mathrm{N} 70^{\circ} \mathrm{E}$ for about $1000 \mathrm{~km}$ and links the western and eastern parts of the fault characterized by active thrusting splays in the western Kunlun foreland and in the Qilian Shan, respectively (Meyer et al., 1998; Tapponnier et al., 2001b).

At about $92^{\circ} \mathrm{E}$, the eastern section splays into two sub-parallels faults and branches that veer to the southeast as thrusts along the ranges of the Qilian Shan and it 
is proposed that its slip-rate decreases towards northeast (Meyer et al., 1998; van der Woerd et al., 2001; Mériaux et al., 2005; Xu et al., 2005).

To the southwest, the Altyn Tagh fault maintains a N70 strike up to $84^{\circ} \mathrm{E}$ where it reaches the complex triple junction between the Karakax fault, the Longmu-Gozha fault and the central Altyn Tagh fault (Tapponnier and Molnar, 1977; Armijo et al., 1986; Avouac and Tapponnier, 1993; Liu, 1993; Raterman et al., 2007; Leloup et al., 2011). This zone is characterized by thrusts splays to the northwest, like the Kashitashi thrust and normal left-lateral splays to the southwest, like the Ashikule and Kuyake faults (Fig. 1b). These latter faults are linked to the Gozha fault via a set of active north-south normal faults, like the Ping Ding fault responsible of the Mw 7.2 (Yutian) earthquake of 20 March 2008 (Fig. 1b; Elliott et al., 2010). West of the volcano-sedimentary Ashikule basin, i.e. west of $81^{\circ} \mathrm{E}$, the Altyn Tagh fault zone resumes as a single fault trace, the Karakax fault or Kangxiwar fault (Pan et al., 1984; Yang et al., 2005; Fu et al., 2006; Li et al., 2006, 2008), striking $\mathrm{N} 100^{\circ} \mathrm{E}$ for about $400 \mathrm{~km}$ to $77^{\circ} \mathrm{E}$. To the west of $77^{\circ} \mathrm{E}$, the fault trace becomes less clear as it splays into two branches, one towards southwest that joins with the Karakorum fault, another towards northwest into the eastern Parmir structures (Fig. 1).

The Karakax fault thus makes up the northern boundary of a triangular block, the North Qiantang or Tianshuihai block (Matte et al., 1996), limited to the southwest by the Karakorum fault and to the southeast by the Longmu-Gozha fault (Fig. 1a; Avouac and Tapponnier, 1993; Liu, 1993; Raterman et al., 2007; Leloup et al., 2011). The present left-lateral Karakax fault (Peltzer et al., 1989; Li et al., 2005, 2006) is in 
fact re-activating a Jurassic-Cretaceous left-lateral shear zone along the northern boundary of the western Kunlun batholith (Matte et al., 1996; Liu et al., 2001, 2003; Arnaud et al., 2003). The kinematics of the Karakorum and Karakax fault imply that this block is currently extruded towards the east, similarly as central Tibet between the dextral Karakorum-Jiali and sinistral Kunlun faults. Resolution of the velocity triangles at the triple junctions led Liu (1993) to propose that this block also rotates clockwise, a process not taken into account in the recent reconstructions of Raterman et al. (2007). The present strike of the Karakax fault is about $\mathrm{N} 100^{\circ} \mathrm{E}$, thus a difference of about $30^{\circ}$ with the average $\mathrm{N} 70^{\circ} \mathrm{E}$ strike of the ATF. It is tempting to suggest that slip initiated on the Karakax fault at a time (Miocene) when the Karakax fault was aligned with the main ATF. As displacement accumulated along the faults, the Tianshuihai block rotated clockwise towards its present position with development of the Longmu-Gozha fault and active folding in the western Kunlun foreland (Matte et al., 1996; Cowgill et al., 2003; Wittlinger et al., 2004). This evolution is also reflected in the cumulative offsets of the Karakax and Longmu-Gozha faults. While the Longmu-Gozha fault accumulated about $30 \mathrm{~km}$ of offset (Raterman et al., 2007), the Karakax fault accumulated about three times more as evidenced by the present 80-90 km offset of the two largest rivers crossing the fault, the Karakax and Yurunkax rivers (Fig. 1b; Gaudemer et al., 1989; Ding et al., 2004).

Left-lateral slip-rates estimates along the Karakax fault have been determined using a variety of methods and range from about 0 to $25 \mathrm{~mm} / \mathrm{yr}$. Large geomorphic fan and moraine offsets associated to glacial to post-glacial transitions lead to 
estimates of about $20 \mathrm{~mm} / \mathrm{yr}$ (Peltzer et al., 1989; Avouac, 1991). Simplified rigid block models confirm high slip-rate values of 23 and $24 \mathrm{~mm} / \mathrm{yr}$ along the Karakax fault (Armijo et al., 1989; Avouac and Tapponnier, 1993). These results seem to be corroborated by subsequent cosmogenic isotope dating of the fans and moraines yielding a range of 12 to $25 \mathrm{~mm} / \mathrm{yr}$ rate over the late Pleistocene-Holocene period (Ryerson et al., 1999). However, these slip-rates differ widely with recent geodetic estimates, either from GPS ( $7 \pm 3 \mathrm{~mm} / \mathrm{yr}$; Shen et al., 2001; Bannerjee and Bürgmann, 2002) or InSAR (5 $\pm 5 \mathrm{~mm} / \mathrm{yr}$; Wright et al., 2004), while a similar results of 7-9 $\mathrm{mm} / \mathrm{yr}$ is obtained when modeling the combined GPS velocities and geological slip-rates (Loveless and Meade, 2011). In fact, very few field studies focused on the western portion of the ATF (Avouac, 1991; Ryerson et al., 1999; Li et al, 2006, 2008) such as the Karakax and Longmu-Gozha faults. Ongoing work by our group using similar data and methods is underway to better constrain these preliminary fault slip-rate estimates and will be the subject of future publications.

Despite its major role in the present-day tectonics of Tibet, the ATF is not characterized by an important seismic activity as evidenced by the lack of large (Mw > 7.5) earthquake in instrumental or historical records (Ma, 1989; Ge et al., 1992; China Seismological Bureau, 1992; SBX, 1997). At its eastern extremity, the Changma earthquake of January 1931 is estimated to reach Mw 7.6 and occurred along a left-lateral thrusting splay to the south and southeast of Changma (Fig. 1; Peltzer et al., 1988; Ge, 1992). Maximum left-slip is estimated to reach about $6 \mathrm{~m}$ with maximum vertical displacements of a few meters (Peltzer et al., 1988). The other 
events known along the fault are the 1924 events of July $3^{\text {rd }}$ and July $12^{\text {th }}$ at the western end of the central section of the fault (Fig. 1; Ge et al., 1992; Feng, 1997; CENC, 2008). These paired events of magnitude Ms 7.2 and 7.5 near Kuyake despite being located northwest of the major ATF fault trace may well have occurred on the ATF, but without clear co-seismic evidence or mechanisms, occurrence along the southeast dipping Kashitashi thrust is not excluded (Fig. 1). Additional events of magnitude $\mathrm{Mw} 7-7.8$ are inferred in its central part (between $89.9^{\circ} \mathrm{E}$ and $91.3^{\circ} \mathrm{E}$ ) along a $150 \mathrm{~km}$ strand from trenching and geomorphic offset analysis (Washburn et al., 2001, 2003). Two to 3 events identified in trenches have occurred in the last 2700 years, the last event between 1250 and 1270 cal. yrs AD, with a recurrence time ranging from 300 to 1400 years and maximum co-seismic offsets of 4 to $7 \mathrm{~m}$ (Washburn et al., 2001). No other large events are known along the ATF or the Karakax fault. Recent seismicity along the Karakax fault is characterized by a few events of magnitude $\mathrm{Mw}<5$ near its eastern extremity, with oblique slip but left-lateral on the east-west trending nodal plane (Fig. 1). The last largest event recorded near the ATF is the normal faulting event of 20 March 2008 along the West Pingding fault, south of the Ashikule basin, in the extensional step-over between the Ashikule and Gozha left-lateral faults (Fig. 1; Elliott et al., 2010).

\section{The Karakax fault surface rupture}

In an effort to better document the past seismic activity of the ATF we describe below evidence for co-seismic offsets of several large events along the Karakax fault. 
At large scale, the Karakax fault is a linear $400 \mathrm{~km}$-long $\mathrm{N} 100^{\circ} \mathrm{E}$ striking fault between 77 and $81^{\circ} \mathrm{E}$ (Fig. 1b). The active fault trace is particularly clear in the bottom of the valleys occupied by the two large Karakax and Yurunkax rivers, both left-laterally about $80 \mathrm{~km}$ along the fault (e.g, Gaudemer et al., 1989; Ding et al., 2004). Between these valleys, east of Kangxiwa, the fault trace is found at higher elevation and its trace is less clear (Fig. 2a). West of the releasing bend of Kangxiwa, where the fault makes a left-step of about $3 \mathrm{~km}$ (Fig. 2a), the fault trace can be followed continuously for about $100 \mathrm{~km}$ cutting through alluvial fans and moraines abandoned by tributaries of the Karakax fed by melting glaciers of the western Kunlun summits. The Karakax river remains mostly on the southern side of the valley, thus south of the fault trace, due to the more actively depositing tributaries from the steeper northern range, probably owing to a small component of uplift (Fig. 2). Where the Karakax river leaves the valley to resume its northerly course (Fig. 2), west of Sanshiliyingfang, the fault trace crosses the river and is then seen on the southern side of the valley.

This study is aimed at describing more specifically the $60 \mathrm{~km}$ section between west of Sanshiliyingfang and Kangiwa, where the fault trace is underlined by well preserved ground disruptions of past ruptures and numerous geomorphic offsets of various amplitudes. The numerous channels, fans and terrace risers offsets, as well as, pressure ridges, pull-apart grabens attest the Karakax fault underwent important left-lateral movement during the late Quaternary (Peltzer et al., 1989; Fu et al., 2006; Li et al., 2008). 


\subsection{Geomorphic offset measurements}

To document the distribution of slip along the rupture trace of the Karakax fault, we collected offset data from field observations and from high resolution satellite images (e.g. Armijo et al., 1989; Van der Woerd et al., 2002; Li et al., 2005; Klinger et al., 2011). Different sets of data were collected during several field campaigns that were either located via portable GPS, or on satellite images or on maps. Field offset measurements were usually made using a tape. A few larger offsets were obtained from total station measurements at specific sites (see site 2 below). Here we gathered all the data in a unique offset database. Field measurements were checked against offsets measured on high-resolution images by reporting their locations on the images. Some co-seismic offsets of small size or not well identified on the images were kept in the database as "field" measurements (see Table 2). All other measurements were checked against measurements from the images. For simplicity, while all offsets are located with their geographical coordinates, they are also located with their distance along the fault from an arbitrary reference taken at longitude $78^{\circ} \mathrm{E}$ (positive eastward, negative westward) (Tables 2 and 3; Figs. 5, 14 and 15).

It should be noted that all offsets reported here are from natural geomorphic markers, no man-made features were measured, so that the initial geometry of the markers may be subject to different interpretations. Uncertainties related to the measurements are thus of different nature. Targeting the best preserved markers and unambiguous offsets, uncertainties related to measurements made in the field are 
usually small (less than 10\%). For offsets determined on the images only, uncertainties will depend mostly on the geometry of the marker. For straight markers, like a linear incised stream or a riser, there is usually no ambiguity to reconstruct the initial geometry, and the error is usually symmetric and small (on the order of the image pixel, i.e., $1 \mathrm{~m}$ ). Other offsets are less well determined and are subject to various interpretations, and in this case bounds of the offset are assessed based on the confidence in the reconstructed geometry.

We selected two sites along the $60 \mathrm{~km}$ long stretch investigated in this study for the quality of offset markers and their overall demonstrative purpose, and also because offsets are not regularly distributed along the fault due to uneven preservation of the geomorphic markers. The first site is located at a place of numerous relatively young channels incised in the same fan surface that are offset due to the last earthquakes. The second site is located near an actively incising river that has abandoned terraces, which are progressively offset by the movement on the fault.

\subsection{Sanshiliyingfang fan site (site 1)}

Site 1 is located 1 to $2 \mathrm{~km}$ west of the city of Sanshiliyingfang where the Karakax fault is cutting through a $1.5 \mathrm{~km}$-wide fan deposited by a tributary of the Karakax (Figs. 2c and 4). There the surface rupture of past earthquakes is particularly clear and relatively narrow (Figs. 3 and 5) and due to numerous channels incised on the fan surface many offsets can be determined (Figs. 3b and 5). No vertical displacement is observed along the rupture trace or only locally due to extensional sags or 
compressional push-up hills. At places the rupture is a single strand (Fig. 6) while at others it is made of stepping sub-parallel strands (Fig. 7).

Most of the offsets identified at site 1 result from the displacement of secondary rills incised at the fan surface. Due to successive phases of renewed incision, the rills and channels are of different width and length and integrate the slip history over different time spans. At some places, along the same channel, offsets are multiples of the smallest measurable offset and thus indicate the progressive accumulation of displacements due to successive earthquakes. At other places only the cumulative displacement can be measured with confidence.

Places were offset were determined are numbered from 1 to 29 from west to east along the fault trace at site 1. A total of 46 offsets were measured at site 1 (Fig. 6; Table 2). The offset \#1 is the cumulative offset of the fan western rim (Figs. 3 and 6). It is also an example, which shows that despite the rather simple shape of the marker (northwest facing riser) its changing geometry across the fault zone and its degradation in the vicinity of the fault various reconstruction lead to a wide range of possible reconstructions. For instance, the average strike of the riser is $\mathrm{N} 80^{\circ} \mathrm{E}$ and $\mathrm{N} 56^{\circ} \mathrm{E}$, north and south of the fault, and because of degradation of the riser near the fault trace, the riser is well marked only about $10 \mathrm{~m}$ away from the fault (Fig. 6). Thus depending on where the strike change occurred, either progressively or, south or north of the fault, the offset ranges from 18 to $29 \mathrm{~m}$ with an average around $24 \mathrm{~m}$. The riser offset (offset \#1) is thus determined at $24 \pm 6 \mathrm{~m}$ (Table 2; Fig. 5).

At some places the offset measurements involve interpretation of both faulting 
evolution and progressive channel incision and capture. Around channels 14 to 17 (Figs. 5, 7 and 8), two main faults cut the channels that developed during the history of faulting. We interpret the various ranges of offsets to testify of the accumulation of slip during large slip events. 4 sets of offset can be determined (Fig. 8) of about 6-8 $\mathrm{m}, 13-16 \mathrm{~m}, 17-21 \mathrm{~m}$ and $27-28 \mathrm{~m}$.

Clearly, all channels recorded the last and most recent increment of slip of about 6 to $8 \mathrm{~m}$ (Fig. 8e), but only a few larger ones recorded the larger offsets, implying that some channels evolved in the course of the slip history depicted here. Note that the largest offset measured here is on the same order as the maximum offset of the fan rim, offset value that may correspond to the phase of incision that followed fan abandonment. Overall, the offsets range from 5 to $30 \mathrm{~m}$, with the most numerous offsets in the range of 6 to $10 \mathrm{~m}$ (Fig. 5c; Table 2).

\subsection{Taersayijilega terraces (site 2)}

Site 2 is located downstream of the Taersayijilega River, at the $369 \mathrm{~km}$ milestone of the Xinjiang-Xizang Highway, 5 km east of Sanshiliyingfang (Figs. 2 and 9). On the northern side of the Karakax river, the glacial meltwater have emplaced a set of alluvial fans and terraces, which are cut and left-laterally offset by the Karakax fault (Figs. 9 and 10).

Combining the analysis of the high-resolution Ikonos images and field observations, and leveling of 11 high-resolution profiles parallel or perpendicular to the fault zone (P1 to P11 on Fig. 10a), we mapped a set of five main terrace levels 
abandoned by the Taersyijilega river. This site is typical of the deposits abandoned by the largest tributaries of the Karakax river. The highest alluvial level is commonly a fan-shape deposit, about $100 \mathrm{~m}$ high above the present stream-bed. Subsequent alluvial terraces were emplaced below this surface as the river started to incise. At site 2, the river incised progressively from the middle of the highest fan surface towards west, so that the terraces were only preserved on its left bank, i.e. to the east of its present bed.

Figure 11 also shows that the T5/T4 riser average height is $16 \mathrm{~m}$; T4/T3' riser is $30 \mathrm{~m}$; T3'/T3 riser is $5 \mathrm{~m}$; T3/T2 riser is $11 \mathrm{~m}$; T2/T1 riser is $9 \mathrm{~m}$; T1/T0' riser is $2 \mathrm{~m}$; and $\mathrm{T}^{\prime} / \mathrm{T} 0$ riser average height is $1 \mathrm{~m}$. We also note that $\mathrm{T} 4$, south of the fault, which is not sloping sub-parallel to the other terrace levels (Fig. 11) is probably of mixed origin, being probably partly formed by deposits of the Taersayijilega river but also from the Karakax river. Clearly, all terrace levels below T4 on the southern side of the fault were abandoned by the Taersayijilega river.

Site 2, with its 10 offset inset terrace levels, from the present river bed to the oldest terrace T5, is a typical site where the space-time evolution of the fault activity may be reconstructed (e.g. Lensen, 1968; Weldon and Sieh, 1985; Gaudemer et al., 1995; Van der Woerd et al., 1998, 2002). Here, a series of left-lateral offsets were obtained that range from 6 to about $250 \mathrm{~m}$ (Fig. 10b): T4/T3' riser is offset by $\sim 255$ $\mathrm{m}$; T3'/T3 riser by $250 \mathrm{~m}$; T3/T2 riser by $\sim 195 \mathrm{~m}$; and T2/T1 riser by $\sim 20 \mathrm{~m}$ (Fig. 13a). Near the river bed (Fig. 12a), T1/T0' riser is offset $12 \mathrm{~m}, \mathrm{~T} 0$ '/T0 riser is offset 6 m (Fig. 13b). Ongoing work by our group on the chronology of the terraces will help 
assess the long term slip-rate of the Karakax fault and will be published in a future article.

Here we concentrate on the observation of the smallest terrace riser offsets between $\mathrm{T} 2$ and the present river bed (Figs. 10b and 12). Both measurements in the field and measured on the images (Fig. 12) indicate that the smallest offset, measured along the lowest terrace riser (T0'/T0) is about $6 \mathrm{~m}$. The next offset is about $12 \mathrm{~m}$ and corresponds to the next upper riser (T1/T0') and other channels incised in the terrace. The $20 \mathrm{~m}$ offset correspond to the riser between $\mathrm{T} 2$ and $\mathrm{T} 1$.

Preserved terrace risers are ideal horizontal displacement markers. Unlike stream channels, once abandoned they will not be reshaped by subsequent erosion or incision. There is no obvious reason that a riser must form between each large earthquake, and it is possible that even the smallest offset measured here represents the cumulative displacement of several earthquakes. The observation at this site, in addition to the observations made elsewhere that the set of offsets are multiple of each other, however, favors an interpretation of repetition of large events. Here, 6, 12 and $20 \mathrm{~m}$ may well be the markers of the last, penultimate and ante-penultimate seismic events along the Karakax fault.

\subsection{Systematic offsets of alluvial channels}

We have determined in a similar way as at site 1 and 2 the offsets along the 55 $\mathrm{km}$ section of the Karakax fault between about $78^{\circ} \mathrm{E}$ and $78.5^{\circ} \mathrm{E}$ (Figs. 2 and 14). A total of 175 offsets were determined that range from $3 \mathrm{~m}$ to about $250 \mathrm{~m}$ (Fig. 14; 
Table 2). While the variability of offsets is large along the fault stretch, a large number of the offsets fall in the range of 3 to $11 \mathrm{~m}$ ( $60 \%$ of the offsets).

At places like site 1 or site 2, and elsewhere along the fault, measurements of the smallest offsets were done in the field in addition to the image interpretation so that there is no ambiguity that the group of smallest offset between 3 and $11 \mathrm{~m}$ can be attributed to the last rupturing event along the fault. Small offset of $3 \mathrm{~m}$ are well preserved at some places and were precisely measured. The precise mapping done at site 1 where offsets are not smaller than $5 \mathrm{~m}$ shows that the minimum offset values along the rupture trace change along strike. The average of these smallest offsets is $6.6 \pm 2.1 \mathrm{~m}$ (full range is $7 \pm 4 \mathrm{~m}$; Fig. 15).

Larger offsets are thus cumulative offsets due to several earthquakes. In particular, like at site 1 or site 2 , when larger offsets are multiples of the smallest offset measured at the same site it is tempting to interpret these larger cumulative offsets as the results of seismic events with similar slip. Overall, along the fault section investigated, larger offsets fall in groups around $14 \pm 2 \mathrm{~m}, 19 \pm 2 \mathrm{~m}$ and $24 \pm 3$ m (Fig. 15), which may well represent resulting slip of 2, 3 and 4 earthquakes with similar co-seismic slip of 6 to $7 \mathrm{~m}$.

\section{Dating of the most recent and penultimate event}

To constrain the timing of the recent events along the Karakax fault we undertook a paleoseismic investigation across the rupture zone. For this investigation to be successful it is important to select a site with sufficient sedimentation and also that the 
sediments be datable. These conditions are not met across the recent stream bed of the tributary of the Karakax, which are intermittent streams that deposit boulder debris flow. For these reasons we selected a site near the bottom of the meandering Karakax river, where fine grained overbank deposits may be deposited during flooding. We choose a site west of site 2 , along a stretch of the fault where the fault is marked by a 1 to $2 \mathrm{~m}$ high scarp indicating a component of vertical displacement. The trench was dug in the vicinity of a clear horizontal channel offset of $6 \mathrm{~m}$ attributed to the last rupturing event along the fault (Fig. 16).

The trench was dug perpendicular to the fault strike; it is several tens of meters long and $3 \mathrm{~m}$ deep in the fault zone. A detailed mapping of the fault breaks visible in the trench walls is shown for the eastern wall in Fig. 17. Five main sedimentary units can be distinguished. At the bottom we found a yellowish wet silty-sand with some fine grained gravels slightly dipping towards south. This unit is covered by a thick 0.5-1m-thick layered gravel unit that thickens toward south canceling any pre-existing relief formed by the lower unit. Above it, a finer unit is found with more angular cobbles. The 2 upper units are silty sands units, the lower one being more silty than the upper one. All units are warped across the fault zone or dipping south, and thicken towards south as wedges in the slope of the fault scarp. As expected all units are mostly fine grained material, that were deposited either close to horizontal as overbank deposit of the Karakax or slightly dipping towards south as fine grained debris from the small south-flowing intermittent stream.

Two sets of faults can be seen cutting through the different units. A first set of 
faults (F1) is not cutting through the two upper silty units and probably predates deposition of the two upper layers. A second set of faults (F2) developed to the north of F1 and cuts all the units and reaches the ground surface. While all faults may have developed as F1 faults, only a subset of those has reached the surface during the last event. We thus take these observations in the 1.5-2 $\mathrm{m}$ upper deposits as evidence for 2 large surface rupturing events.

A charcoal samples was collected at a depth of $\sim 65 \mathrm{~cm}$ in the silty layer above the gravel unit ruptured by faults F1. As this silty unit postdates faults F1 it may put an upper bound on the age of the penultimate event along the fault. The radiocarbon age was determined at the Accelerator Mass Spectrometry Laboratory, Peking University and calibrated at 975-1020 A.D. cal years (Fig. 17; Table 3).

The charcoal sample is found just above the faulted gravel units in a silty sediment, not able to abrade the coarser gravels below. The radiocarbon age is thus interpreted as post-dating closely the ruptures of faults F1. While we cannot precisely determine the time-gap between the rupturing event F1 and deposit of the dated unit above, the evidence at hand indicate that 2 earthquakes, including the last event with about $6 \mathrm{~m}$ co-seismic horizontal offset, occurred in at least the last 980-1035 years.

The date of the most recent event is unknown. Historical accounts of large events in the region are rare. If we take into account possibilities of mislocation or unknown source for the largely felt events of 1902 or 1882 in the cities of Pishan and Hotan (Fig. 1b; Table 1), these events could be attributed to slip on the Karakax fault about $150 \mathrm{~km}$ to the south. The well preserved rupture trace and numerous evidence of 
ground ruptures along the Karakax fault indicate that the event must have occurred at most one or two centuries ago.

\section{Discussion}

\subsection{Left-lateral offsets and large earthquakes}

Well documented offset distributions of large strike-slip earthquakes are rather rare. Recent strike-slip fault events (Izmit, 1999; Kunlun, 2001; Denali, 2002) have renewed interest in surface slip distributions as an insight, for example, into the mechanics of faulting (Haeussler et al., 2004) or the underlying crustal structure (Klinger et al., 2006; Klinger, 2010).

At a local or regional scale there is an interest in better documenting the recent events along the Karakax fault. Indeed, it is perhaps the most recent large seismic event to have occurred along the Altyn Tagh fault. Nowhere along the fault are surface ruptures so well preserved as along the western section of the Karakax fault. While the long-term slip-rate of the Altyn Tagh fault is a subject of debate, questioning the role of the Altyn Tagh fault in the geological evolution of Tibet and its role in the India-Asia collision, the absence of well documented recent large seismic events along its entire length comes into addition to the oddity of having a fast slipping fault (1-2 cm/yr) without seismicity.

Another important implication of this work concerns the seismic risk posed by a large seismic event for the city of Yecheng, Pishan and Hotan at a straight distance from the fault of about $120 \mathrm{~km}$. 
This study focused on a section of about $55 \mathrm{~km}$ between west of Sanshiliyingfang and Kangxiwa, which is the most easily accessible stretch of the fault in the field. There is, however, evidence that the rupture is not terminating west or east of the study area. Googlearth imagery indicates clearly that towards west the rupture continues for at least $40 \mathrm{~km}$. Towards east the situation is less clear. East of Kangxiwa the trace of the fault disappears in the active river bed of the Karakax, we have no evidence that the rupture continued farther east. From the distribution of slip attributed to the last event along the $55 \mathrm{~km}$ (Fig. 15), to the west, the slip is near its maximum between 6 and $10 \mathrm{~m}$, so it is not surprising to observe a continuation of the rupture for about $40 \mathrm{~km}$. To the east, however, the slip distribution show lower values down to about $3 \mathrm{~m}$ that may indicate that the rupture end is close to its end near or east of Kangxiwa (Figs.14 and 15).

The length of the studied rupture, $55 \mathrm{~km}$, and the average co-seismic offsets of $6.6 \pm 1.2 \mathrm{~m}$ are compatible with a magnitude Mw 7.4 event (Wells and Coppersmith, 1994). We have considered a seismogenic thickness of $15 \mathrm{~km}$, a value compatible with the recent seismic events of northern Tibet, like the Manyi event of 1997 (Mw 7.6; Peltzer et al., 1999) or the Kokoxili earthquake of 2001 (Mw 7.9; Van der Woerd et al., 2002; Lasserre et al., 2005; Tocheport et al., 2006). This value is also in agreement with the depth of the modeled slip on the normal faulting event along the Pingding fault in the western Kunlun (Eliott et al., 2010).

Adding $40 \mathrm{~km}$ of rupture to the west, and taking the same average co-seismic offset of $6.6 \mathrm{~m}$ makes it a magnitude $\mathrm{Mw}$ 7.6. It is possible that the rupture is longer 
towards the east, or that splaying branches may have broken during this event to the west of the east of the recognized rupture. In any case, even if the rupture might be longer, it is likely that the average slip would be slightly smaller, and thus that the range of magnitude defined here are correct. It is thus implied that the maximum slip during the last event did occur in the section studied, and particularly the western part around our site 1. Maximum co-seismic slip in events with surface ruptures less than $150 \mathrm{~km}$-long rarely reach 6-8 $\mathrm{m}$ as seem to be the case here. Usually, magnitude $\mathrm{Mw}$ 7.4 -7.6 events have length over $150 \mathrm{~km}$. The 1997 Manyi event had a maximum slip of about $7 \mathrm{~m}$ but a rupture length of $170 \mathrm{~km}$ (Peltzer et al., 1999). The Mw 7.4 Izmit event of 1999 along the North Anatolian fault with a rupture length of $150 \mathrm{~km}$ reached a maximum co-seismic offset of $5 \mathrm{~m}$. It is comparable to the Fuyun earthquake of 1931 estimated to reach Mw 7.6 with an average slip of $6 \mathrm{~m}$ and a rupture length about $160 \mathrm{~km}$ (Klinger et al., 2011).

\subsection{Characteristic slip}

The observation from the field at local sites that cumulative offsets are multiple of the smallest offset (about 6-8 $\mathrm{m}$ at site 1 and $6 \mathrm{~m}$ at site 2), with no evidence of intermediate values, indicate that the co-seismic slip during the last 2, 3 or 4 events was almost constant at these sites and indicate characteristic behavior (e.g. Sieh, 1996; Klinger et al. 2011). The use of high resolution images allows to extend this observation and to propose that the geomorphic offsets measured along the $55 \mathrm{~km}$ section of the Karakax fault are organized in distinct clusters that may represent the 
repetition of similarly sized events with an average co-seismic slip of $6.6+1.2 \mathrm{~m}$ (Fig. 15). Our data is too sparse, in particular the cumulative offset data, to really show evidence of offset clusters and as observed elsewhere, cumulative offsets tend to be less numerous as they become larger (e.g. van der Woerd et al., 2002; Klinger et al., 2011). However, the precise observations at distinct sites (e.g. site 1 or site 2) that the larger cumulative offsets are multiple of the most recent one are in favor of the repetition of similar slipping events. While slip distributions may show large variations between events, the similar slip observed for the last 3 to 4 events at one site may indicate that it is the case for the entire section studied, unless one imagines very abrupt changes in slip along strike for which we have no evidence.

Co-seismic slip distributions may show large variations along strike (e.g. Chen et al., 2003; Klinger et al., 2005; Fu et al., 2005) that may be difficult to interpret in the frame of a characteristic slip model, unless smaller events occur to smooth out the cumulative slip distribution (e.g. Ward, 1997; Tapponnier et al., 2001b; Liu-zeng et al., 2006). However, observation of repetition of similar sized events have been done at several places, although usually only locally along the faults (e.g. Peltzer et al., 1988; Lasserre et al., 1999; Tapponnier et al., 2001b; van der Woerd et al., 2002; Liu-Zeng et al., 2004).

\subsection{Earthquake recurrence interval}

Even though no large earthquake $(M \geq 7)$ was recorded along the Karakax segment of the western Altyn Tagh fault (SBX, 1997; Feng, 1997), the 80-100 km-long surface 
rupture zone observed along the Karakax valley (Fu et al., 2006; Li et al., 2008) attest of the occurrence of recent large seismic events $(M \geq 7)$. Near site 2 along the Karakax fault, the ${ }^{14} \mathrm{C}$ age obtained for the sediment unit capping the penultimate event (975-1020 A.D. cal years; Table 3; Figs. 16 and 17) and the geomorphic evaluation that the most recent event must have occurred 100 to 200 years ago (perhaps the historical event of 1882), constrains the recurrence time between large events to at least 900-1000 years.

The earthquake recurrence intervals in the late Cenozoic are different along different segments of the Altyn Tagh fault (Ding, 1995). Along the central Altyn Tagh fault, the recurrence period of inferred $M w \geq 7$ earthquakes is estimated between $0.7 \pm 0.4$ ka to $1.1 \pm 0.3 \mathrm{ka}$ according to paleo-seismic research (Washburn et al., 2001)

\subsection{Average slip-rate of the Karakax fault}

The different scales of geomorphic deformation in this area such as river offsets, moraine/alluvial fans and terraces, pull-apart graben and push-up ridges are the cumulative result of many seismic events in Quaternary, attesting of the long-term left-lateral strike-slip movement along the Karakax segment of the western Altyn Tagh fault. Large left-lateral cumulative river offsets such as the Karakax and Yurunkax of about $80 \mathrm{~km}$ (Fig. 1b) testify also of continuous activity of the Karakax fault in the late Cenozoic (Gaudemer et al., 1989; Ding et al., 2004).

In the Karakax (or Kangxiwar) segment of western Altyn Tagh fault, the possible slip-rate during the late Quaternary had been estimated to be $20 \sim 30 \mathrm{~mm} / \mathrm{a}$ (Peltzer, et 
al., 1989), 6.5-10 mm/a (Ding et al., 2004) and 8-12 mm/a (Fu, et al., 2006), according to the offset and age estimation, and $12-23 \mathrm{~mm} / \mathrm{a}$ according to the surface exposure age and displacement of river terraces (Ryerson et al., 1999). Both the accuracy of the dating methods and the interpretation of the relationship between ages and offsets contribute to an ongoing debate over the Karakax fault slip-rate. Recently, some studies determined slip-rates of $7 \pm 3 \mathrm{~mm} / \mathrm{a}$ obtained from GPS observation (Shen et al., 2001) and $5 \pm 5 \mathrm{~mm} / \mathrm{a}$ from InSAR (Wright et al., 2004), rates that thus range from 0 to $10 \mathrm{~mm} / \mathrm{yr}$.

The data presented here may add some constrain on the slip-rate. In particular the age constraints from the trench west of site 2, although based on a unique sample from a single trench wall interpretation. Several hundreds of meters east of the trench, various rill channels are left-laterally offset by $6 \mathrm{~m}$ and $14 \pm 2 \mathrm{~m}$ that might be produced by the latest and the penultimate seismic events. Given the recurrence time of at least 900-1000 years determined and the average co-seismic slip of $6.6 \mathrm{~m}$, a maximum slip-rate of about 6-7 $\mathrm{mm} / \mathrm{yr}$ may be determined. Given the uncertainty in the return time of earthquakes, this rate is preliminary, and more evidence from paleoseismic trenching or geomorphic dating is necessary to better constrain the ages of the 3 to 4 last large events described in this study. Particularly, our geomorphic mapping of alluvial terraces at site 2 and the associated offset measurements (Fig. 10) demonstrate the potential of long-term slip-rate determination along the Karakax fault that we will address in a future publication. 


\section{Conclusions}

Along the western section of the Karakax fault, between Sanshiliyingfang fan (site 1) and Kangxiwa (Figs. 2 and 14) we have measured a set of 175 offsets, from which $60 \%$ (107) result from co-seismic slip of the last large earthquake (Table 2). This result has been obtained from field measurements and observations, complemented with data from high resolutions satellite images. The average slip of the last earthquake over the $55 \mathrm{~km}$ fault stretch investigated is $6.6 \pm 2.1 \mathrm{~m}$, and evidence of a rupture length of at least $100 \mathrm{~km}$, the magnitude of the earthquake probably reached Mw 7.4-7.6 (Wells and Coppersmith, 1994).

Cumulative displacements of $14 \pm 2,19 \pm 2$ and $24 \pm 3 \mathrm{~m}$ are interpreted as evidence of repeated earthquakes with similar co-seismic slip of about 6 to $7 \mathrm{~m}$ and suggestive of a characteristic slip faulting behavior for at least the last 4 events along the Karakax fault.

According to the AMS ${ }^{14} \mathrm{C}$ age of $975 \sim 1020$ A.D. of a layer capping the breaks interpreted to belong to the penultimate event, and the geomorphic freshness of the most recent event, a tentative recurrence time for large events is estimated of about 800 to 1000 years. Estimating that the most recent event occurred in the last century (or $200 \mathrm{yrs}$ at most), it may be related to the historical events of 1902 or 1882 located south of Pishan and Hotan (Fig. 1; Table 1).

Considering a constant slip-rate, the co-seismic slip of $6.6 \mathrm{~m}$ and the recurrence time of $900 \pm 100$ years for large surface breaking events define an average slip-rate for the Karakax fault of about 6-7 mm/yr. Evidence of large left-lateral cumulative 
displacements suggest that the Karakax fault is the largest left-lateral strike-slip fault at the rim of northwestern Tibet accommodating eastward movement of Tibet due to the India-Eurasia collision.

\section{Acknowledgments}

We thank Professor Xu Zhiqin for helpful discussion on the tectonic history of the fault, Mr. Sun Hailin and Mr. Pen Huahui for their help in the field. We thank Gilles Peltzer, Jean-Philippe Avouac and Frederik J. Ryerson for sharing their field observations acquired during fieldtrips in 1989, 1990 and 1995 organized between CAGS and IPGP (Paris, France), JPL and LLNL (CA, USA) and two anonymous reviewers helped us to greatly improve the manuscript. SPOT images were acquired thanks to programme Tectoscope between INSU-CNRS and CNES (France). This study was financially supported by the projects from the China Geological Survey (Nos: 1212010918036, 1212011121267). We thank the AMS Laboratory, the school of archaeology and museology, Beijing University for the AMS ${ }^{14} \mathrm{C}$ dating. 


\section{References}

Armijo, R., Tapponnier, P., Mercier, J.L., Han T., 1986. Quaternary extension in southern Tibet: field observations and tectonic implications. Journal of Geophysical Research 91, 13803-13872.

Armijo, R., Tapponnier, P., Han, T., 1989. Late Cenozoic right-lateral strike-slip faulting in southern Tibet. Journal of Geophysical Research 94, B3, 2787-2838.

Arnaud, N., Tapponnier, P., Francoise, R., Brunel M., Schärer U., Chen, W., Xu, Z., 2003. Evidence for Mesozoic shear along the western Kunlun and Altyn-Tagh fault, northern Tibet (China). Journal of Geophysical Research 108(B1), ETG 12-1-12-27.

Avouac, J.P., Tapponnier, P., 1993. Kinematic model of active deformation in Central Asia. Geophysical Research Letters 20(10), 895-898.

Avouac, J.P. 1991. Applications des methodes de morphologie quantitative à la néotectonique. Modèle cinématique des deformations actives en Asie Centrale. PhD dissertation, University Paris VII, Paris, France, 156p.

Bendick, R., Bilham, R., Freymueller, J., Larson, K., Yin, G., 2000. Geodetic evidence for a low slip rate in the Altyn Tagh fault system. Nature 404, 69-72.

CENC, 2008. China Earthquake Networks Center. Website : http://www.csndmc.ac.cn/

Chen, J., Chen, Y., Ding, G., Tian, Q., Wang, Z., Shan, X., Ren, J., Zhao, R., Wang, Z., 2003. Surface rupture zones of the 2001 earthquake MS 8.1 west of Kunlun pass, northern Qinghai-Xizang Plateau. Quaternary Sciences 23(6), 629-639 (in 
Chinese, with English abstract).

China Seismological Bureau "The Altun Active Fault Zone" ed. 1992. The Altun Active Fault Zone. Beijing: Seismological Press 1-319 (in Chinese).

Cowgill, E., Yin, A., Harrison, T.M., Wang, X.-F., 2003. Reconstruction of the Altyn Tagh fault based on U-Pb ion microprobe geochronology: Role of back thrusts, mantle sutures, and heterogeneous crustal strength in forming the Tibetan Plateau. Journal of Geophysical Research 108, 2346, doi10.1029/ 2002JB002080.

Cowgill, E,. 2007. Impact of riser reconstructions on estimation of secular variation in rates of strike-slip faulting: Revisiting the Cherchen River site along the Altyn Tagh Fault, NW China, Earth and Planetary Science Letters 254(3-4), 239-255.

Cowgill, E., Gold, R.D., Chen, X., Wang, X.F., Arrowsmith J.R., Southon, J., 2009. Low Quaternary slip rate reconciles geodetic and geologic rates along the Altyn Tagh fault, northwestern Tibet. Geology 37, 647-650.

Ding, G., 1995. Paleoearthquakes along the Altun active fault and its segmentation. Quaternary Sciences 2, 97-106 (in Chinese, with English abstract).

Ding, G.Y., Chen, J., Tian, Q.J., Shen, X.U., Xing, C.Q., Wei, K.B., 2004. Active faults and magnitudes of left-lateral displacement along the northern margin of the Tibetan Plateau. Tectonophysics 380 (3-4), 243-260.

Elliott, J.R., Walters, R.J., England, P.C., Jackson, J.A., Li, Z., Parsons, B., 2010. Extension on the Tibetan plateau: recent normal faulting measured by InSAR and body wave seismology. Geophysical Journal International 183, 503-535, doi: 10.1111/j.1365-246X.2010.04754.x. 
Feng, X., 1997. Palaeo-earthquakes of Xinjiang. Ürümqi: Science, Technology and Health Publishing House, 1-250 (in Chinese).

Fu, B., Awata, Y., Du, J., Ninomiya, Y., He, W., 2005. Geometry and segmentation of the surface rupture associated with the 14 November 2003 giant Kunlun earthquake, northern Tibet, China. Tectonophysics 407, 43-63.

Fu, B., Zhang, S., Xie, X., Shi, X., Wang, S., 2006. Late Quaternary tectono-geomorphic features along the Kangxiwar fault, Altyn Tagh fault system, Northern Tibet. Quaternary Sciences 26(2), 228-235 (in Chinese, with English abstract).

Fumal, T.E., Pezzopane, S.K., Weldon, R.J., Schwartz, D.P., 1993. A 100-year average recurrence interval for the San Andreas fault at Wrightwood, California. Science, 259, 199-203.

Ge, S., Bai, M., Li, Y., Liu, G., Zhen, Q., Zheng, J. Zhu, S., 1992. Active Altyn Tagh Fault Zone, Seismological Press, Beijing, 319p.

Gaudemer, Y., Tapponnier, P., Turcotte, D., 1989. River offsets across active strike-slip faults. Annales Tectonicae 3(3), 55-76.

Gaudemer, Y., Tapponnier, P., Meyer, B., Peltzer, G., Guo, S. M., Chen, Z. T., Dai, H. G., Cifuentes, I., 1995. Partitioning of crustal slip between linked, active faults in the eastern Qilian Shan, and evidence for a major seismic gap, the "Tianzhu gap," on the western Haiyuan fault, Gansu (China). Geophysical Journal International 120, 599-645.

Gold, R., Cowgill, E., Arrowsmith, J. R., Chen, X., Sharp, W. D., Cooper, K. M., 
Wang, X. F., 2011. Faulted terrace risers place new constraints on the late Quaternary slip rate for the central Altyn Tagh Fault, northwest Tibet. Geological Society of America Bulletin, doi:10.1130/B30207.1.

Lasserre, C., Morel, P.-H., Gaudemer, Y., Tapponnier, P., Ryerson, F.J., King, G., Métivier, F., Kasser, M., Kashgarian, M., Liu, B., Lu, T., Yong, D., 1999. Post-glacial left slip-rate and past occurrence of $M \geq 8$ earthquakes on the western Haiyuan fault (Gansu, China). Journal of Geophysical Research 104, 17633-17651.

Lasserre, C., Peltzer, G., Crampé, F., Kligner, Y., Van der Woerd, J., Tapponnier, P., 2005. Coseismic deformation of the $2001 \mathrm{Mw}=7.8$ Kokoxili earthquake in Tibet, measured by synthetic aperture radar interferometry. Journal of Geophysical Research 110, B12408, doi:10.1029/2004JB003500.

Leloup P.H., Arnaud N.O., Mahéo G., Paquette J.L., Guillot, S., Valli F., Li H., Xu Z., Lacassin R., Tapponnier P., 2011. Successive deformation episodes along the Lungmu Co zone, west-central Tibet. Gondwana Research, in press.

Lensen, G.J., 1968. Analysis of progressive fault displacement during downcutting at the Branch River terraces, South Island, New Zealand. Geological Society of America Bulletin 79, 545-556.

Li, H., Yang, J., Shi, R., Wu, C., Tapponnier, P., Wan, Y., Zhang, J., Meng, F., 2002. Determination of the Altyn Tagh strike-slip fault basin and its relationship with mountains. Chinese Science Bulletin 47(7), 572-577.

Li, H., Yang, J., Xu, Z., Wu, C., Wan, Y., Shi, R., Liou, J.G., Tapponnier, P., Ireland, 
T.R., 2002. Geological and chronological evidence of Indo-Chinese strike-slip movement in the Altyn Tagh fault zone. Chinese Science Bulletin 47(1), 28-33.

Li H., J. Van der Woerd, Y. Klinger, P. Tapponnier, Qi X., Yang J., Zhu Y., 2005. Slip rate on the Kunlun Fault and recurrence time of great earthquake comparable to the 14/11/2001, Mw 7.8 Kokoxili earthquake at Hongshui Gou. Earth and Planetary Science Letters 237, 285-299.

Li H., Yang, J., Wu, C., Xu, Z., Tapponnier, P., Arnaud, N., 2005. The evidence for Triassic sinistral shear along the Altyn Tagh fault, northern Tibet (China). Abstract submitted to AGU 2005 fall meeting.

Li, H., Yang, J., Xu, Z., Sun, Z., Tapponnier P., Van der Woerd, J., Meriaux, A., 2006. The constraint of the Altyn Tagh fault system to the growth and rise of the northern Tibetan plateau. Earth Science Frontiers 13(4), 59-79 (in Chinese, with English abstract).

Li H., J. Van der Woerd, Sun Z., Meriaux A-S, P. Tapponnier, F.J. Ryerson, Si J., Pan J., 2008. Late Quaternary left-slip rate and large earthquake recurrence time along the Kangxiwar (Karakax) segment of the Altyn Tagh fault, Northern Tibet. Quaternary Sciences 28(2). 197-217 (in Chinese with English abstract).

Liu, Q., 1993. Paléoclimat et contraintes chronologiques sur les mouvements récents dans l'Ouest du Tibet: failles du Karakorum et de Longmu Co-Gozha Co, lacs en pull-apart de Longmu Co et de Sumxi Co. PhD dissertation, University Paris VII, 360 p.

Liu, Y., Ge, X., Genser, J., Neubauer, F., Friedl, G., Chang, L., Ren, S., Handler, R., 
2003. ${ }^{40} \mathrm{Ar} /{ }^{39} \mathrm{Ar}$ age evidence for Altyn fault tectonic activities in western China. Chinese Science Bulletin 48(18), 2024-2030.

Liu, Y., Ye, H., Ge, X., Chen, W., Liu, J., Ren, S., Pan, H., 2001. Laser probe ${ }^{40} \mathrm{Ar} /{ }^{39} \mathrm{Ar}$ dating of mica on the deformed rocks from Altyn Fault and its tectonic implications, western China. Chinese Science Bulletin 46(4). 322-325.

Liu-Zeng, J., Klinger, Y., Sieh, K., Rubin, C., 2004. Six similar sequential ruptures of the San Andreas fault, Carrizo Plain, California. Geology 32(8), 649-652.

Liu-Zeng, J., Klinger, Y., Sieh, K., Rubin, C., Seitz, G., 2006. Serial ruptures of the San Andreas fault, Carrizo Plain, California, revealed by three-dimensional excavations. Journal of Geophysical Research 111, B02306, doi:10.1029/2004JB003601.

Liu-Zeng, J., Klinger, Y., Xu, X., Lasserre, C., Chen, G.H., Chen, W.B, Tapponnier, P., Zhang, B. , 2007. Millennial Recurrence of Large Earthquakes on the Haiyuan Fault near Songshan, Gansu Province, China. Bulletin of the Seismological Society of America 97, 1B, 14-34, doi:10.1785/0120050118.

Ma, X., 1989. Lithospheric Dynamics Atlas of China. China Cartographic Publishing House, Beijing.

Mériaux, A.S., Ryerson, F.J., Tapponnier, P., Van der Woerd, J., Finkel, R.C., Xu, X., Xu, Z., Caffee, M.W., 2004. Rapid slip along the central Altyn Tagh fault: Morphochronologic evidence from Cherchen He and Sulamu Tagh. Journal of Geophysical Research 109(B6), B06401, doi:10. 1029 /2003JB002558.

Mériaux, A.S., Tapponnier, P., Ryerson, F.J., Xu, X., King, G., Van der Woerd, J., 
Finkel, R.C., Li, H., Caffee, M.W., Xu, Z., Chen, W., 2005. The Aksay segment of the northern Altyn Tagh fault: tectonic geomorphology, landscape evolution, and Holocene slip rate. Journal of Geophysical Research 110, B04404 doi: 04410.01029/02004JB003210.

Meyer, B., Tapponnier, P., Gaudemer, Y., Peltzer, G., Shunmin, G., Chen, Z., 1996. Rate of left-lateral move ment along the easternmost segment of the Altyn Tagh Fault, east of $96^{\circ} \mathrm{E}$ (China). Geophysical Journal International 124, 29-44.

Meyer, B., Tapponnier, P., Bourjot, L., Metivier, F., Gaudemer, Y., Peltzer, G., Guo, S., Chen, Z., 1998. Crustal thickening in Gansu - Qinghai, lithospheric mantle subduction, and oblique, strike-slip controlled growth of the Tibet Plateau. Geophysical Journal International 135(1), 1-47.

Molnar, P., Burchfiel, B.C., Liang, K., Zhao, Z., 1987. Geomorphic evidence for active faulting in the Altyn Tagh and Northern Tibet and qualitative estimates of its contribution to the convergence of India and Eurasia. Geology 15(3), 249-253.

Molnar, P., Tapponnier, P., 1975. Cenozoic tectonics of Asia: Effects of a continental collision. Science 189, 419-426.

Pan, G., Jiao, S., Xu, Y., Wang, P., Xiang, T., 1984. The Cenozoic Tectonics and its Orogeny in Altun. Contribution to the Geology of the Qinghai-Xizang (Tibet) Plateau (15). Beijing: Geological Publishing House 113-119 (in Chinese, with English abstract).

Peltzer, G., Crampé, F., King, G., 1999. Evidence of nonlinear elasticity of the crust 
from the Mw7.6 Manyi (Tibet) earthquake. Science 286, 272-276.

Peltzer, G., Tapponnier, P., 1988. Formation and evolution of strike-slip faults, rifts and basins during the India-Asia collision: an experimental approach. Journal of Geophysical Research 93, B12, 15085-15117.

Peltzer, G., Tapponnier, P., Gaudemer, Y., Meyer, B., Guo, S., Yin, K., Chen, Z. Dai, H., 1988. Offsets of late quaternary morphology, rate of slip, and recurrence of large earthquakes on the Chang Ma fault (Gansu, China). Journal of Geophysical Research 93 (B7), 7793-7812.

Peltzer, G., Tapponnier, P., Armijo, R., 1989. Magnitude of Late Quaternary left-lateral displacement along the north edge of Tibet. Science 246, 1285-1289.

Raterman, N.S., Cowgill, E., Lin, D., 2007. Variable structural style along the Karakorum fault explained using triple-junction analysis of intersecting faults. Geosphere 3, 2, 71-85, doi: 10.1130/GES00067.1.

Ritz, J.F., Brown, E.T., Bourlès, D.L., Philip, H., Schlupp, A., Raisbeck, G.M., Yiou F., Enkhtuyshin, B., 1995. Slip-rates along active faults estimated with cosmic-rayexposure dates: application to the Bogd fault, Gobi-Altaï, Mongolia. Geology 23(11), 1019-1022.

Ryerson, F.J., Peltzer, G., Tapponnier. P., Finkel, R.C., Meriaux, A.S., Van der Woerd, J., Caffee, M.W., 1999. Active slip-rates on the Altyn Tagh fault Karakax valley segment: Constraints from surface exposure dating. EOS (Transactions, American Geophysical Union) 80(47), 1008.

Seismological Bureau of Xinjiang Uygur Autonomous Region (SBX). 1997. 
Instruction of Xinjiang Uygur Autonomous Region seismotectonic map (1:2000000). Chengdu, Chengdu Map Publishing House.

Seismological Bureau of Xinjiang Uygur Autonomous Region (SBX), 2008. Catalog for earthquakes in Xinjiang (1970 2000).

Shen, Z.K., Wang, M., Li, Y., Jackson, D.D., Yin, A., Dong, D., Fang, P., 2001. Crustal deformation along the Altyn Tagh fault system, western China, from GPS. Journal of Geophysical Research 106, 30607-30621.

Tapponnier, P., Molnar, P., 1977. Active faulting and tectonics of China. Journal of Geophysical Research 82, 2905-2930.

Tapponnier, P., Ryerson, F.J., Van der Woerd, J., Mériaux, A.S., Lasserre, C., 2001 a. Long-term slip rates and characteristic slip: keys to active fault behaviour and earthquake hazard. Earth and Planetary Sciences 333, 483-494.

Tapponnier, P., Xu, Z.Q., Roger, F., Meyer, B., Arnaud, N., Wittlinger, G., Yang, J., 2001b. Oblique stepwise rise and growth of the Tibet Plateau. Science 294, 1671-1677.

Tocheport, A., Rivera, L., Van der Woerd, J., 2006. A study of the 14 November 2001 Kokoxili earthquake: history and geometry of the rupture from teleseismic data and field observations. Bulletin of the Seismological Society of America 96, 5, 1729-1741, doi:10.1785/0120050200.

Van der Woerd, J., Ryerson, F.J., Tapponnier, P., Gaudemer, Y., Finkel, R., Mériaux, A.S., Caffee, M., Zhao, G., He, Q., 1998. Holocene left slip-rate determined by cosmogenic surface dating on the Xidatan segment of the Kunlun fault (Qinghai, 
China). Geology 26, 695-698.

Van der Woerd, J., Tapponnier, P., Ryerson, F.J., Meriaux, A.S., Meyer, B., Gaudemer, Y., Finkel, R.C., Caffee, M.W., Zhao, G.., Xu, Z., 2002. Uniform postglacial slip-rate along the central $600 \mathrm{~km}$ of the Kunlun fault (Tibet), from ${ }^{26} \mathrm{Al},{ }^{10} \mathrm{Be}$ and ${ }^{14} \mathrm{C}$ dating of riser offsets, and climatic origin of the regional morphology. Geophysical Journal International 148, 356-388.

Van der Woerd, J., Xu, X., Li, H., Tapponnier, P., Meyer, B., Ryerson, F.J., Meriaux, A.S., Xu, Z., 2001. Rapid active thrusting along the northwestern range front of the Tanghe Nan Shan (western Gansu, China). Journal of Geophysical Research 106(B12), 30475-30504.

Wallace, K., G. Yin, R. Bilham, 2004. Inescapable slow slip on the Altyn Tagh fault. Geophysical Research Letters 31, 1-4, L09613, doi:10.1029/2004GL019724.

Washburn, Z., Arrowsmith, J.R., Forman, S.L., Cowgill, E., Wang, X., Zhang, Y., Chen, Z., 2001. Late Holocene earthquake history of the central Altyn Tagh fault, China. Geology 29(11), 1051-1054.

Washburn, Z., Arrowsmith, J., Nivet. G., Wang. X., Zhang, Y., Chen, Z., 2003. Paleoseismology of the Xorxol Segment of the Central Altyn Tagh Fault, Xinjiang, China. Annals of Geophysics 46(5), 1015-1034.

Weldon, R.J., Sieh, K.E., 1985. Holocene rate of slip and tentative recurrence interval for large earthquakes on the San Andreas fault in Cajon Pass, southern California. Geological Society of America Bulletin 96, 793-812.

Weldon, R., Fumal, T., Biasi, G., 2004. Wrightwood and the earthquake cycle: what a 
long recurrence record tells us about how faults work. GSA Today 14(9), 4-10.

Wells, D.L., Coppersmith, K.J., 1994. New empirical relationships among magnitude, rupture length, rupture width, rupture area, and surface displacement. Bulletin of the Seismological Society of America 84(4), 974-1002.

Wittlinger, G., Vergne, J., Tapponnier, P., Farra, V., Poupinet, G., Jiang, M., Su, H., Herquel, G., Paul, A., 2004. Teleseismic imaging of subducting lithosphere and Moho offsets beneath Western Tibet. Earth and Planetary Science Letters 221 $(1-4), 117-130$

Wright, T.J., Parsons, B., England, P.C., Fielding, E.J., 2004. InSAR observations of low slip rates on the major faults of Western Tibet. Science 305, 236-239.

Xu, X., Deng, Q. 1996. Nonlinear characteristics of paleoseismicity in China. Journal of Geophysical Research 101, B3, 6209-6231.

Xu, X, Tapponnier, P., Van der Woerd, J., Ryerson, F.J., Wang, F., Zheng, R., Chen, W., Ma, W., Yu, G., Chen, G., Mériaux, A.-S., 2005. Late Quaternary sinistral slip rate along the Altyn Tagh fault and its structural transformation model. Science in China (Series D) 48 (3), 384-397.

Yang, W., Zhang, W., Qu, X., 2005. Geochemical evidence of the relation between the Kuyake fault of east part of west Kunlun Mountains and the Kangxiwar and Altyn Tagh faults. Geological Bulletin of China 24(4), 316-321 (in Chinese with English abstract).

Yin, A., Rumelhart, P.E., Butler, R., Cowgill, E., Harrison, T.M., Foster, D.A., Ingersoll, R.V., Zhang, Q., Zhou, X.Q., Wang, X.F., Hanson, A., Raza, A., 2002. 
Tectonic history of the Altyn Tagh fault system in northern Tibet inferred from Cenozoic sedimentation. Geological Society of America Bulletin 114(10), 1257-1295.

Yue, Y., Liou, J.G., 1999. Two-stage evolution model for the Altyn Tagh Fault, China. Geology 27(3), 227-230.

Yue, Y.J., Graham, S.A., Ritts, B.D., Wooden, J.L., 2005. Detrital zircon provenance evidence for large-scale extrusion along the Altyn Tagh fault. Tectonophysics 406, 165-178, doi:10.1016/j.tecto.2005.05.023.

Zhang, J.X., Zhang, Z.M., Xu, Z.Q., Yang, J.S., Cui, J.W., 2001. Petrology and geochronology of eclogites from the western segment of the Altyn Tagh, northwestern China. Lithos 56(2-3), 189-208.

Zhang, P., Molnar, P., Xu, X., 2007. Late Quaternary and present-day rates of slip along the Altyn Tagh Fault, northern margin of the Tibetan Plateau. Tectonics 26(5), TC5010, doi:10.1029/2006 TC002014.

Zhang, Y.Q., Vergely, P., Mercier, J., 1995. Active faulting in and along the Qinling range (China) inferred from SPOT imagery analysis and extrusion tectonics of South China. Tectonophysics 243, 69-95.

Zhang, P., Molnar, P., Burchfiel, B.C., Royden, L., Zhang, W., Jiao, D., Deng, Q., Wang, Y., F. Song, 1988. Bounds on the recurrence interval of major earthquakes along the Haiyuan fault in north-central China. Seismological Research Letters 59, 81-89. 


\section{Figure captions}

Fig. 1 (a) Tectonic map of major active faults of northern Tibet (modified from Tapponnier et al., 2001b). a, b, and c is large scale segmentation of ATF. Green dots are largest historical and instrumental earthquakes with magnitude $>7$ (Ge, 1992; USGS/NEIC). (b) Active fault map of northwestern Tibet. Background is Landsat satellite image. Historical earthquakes from the Seismological Bureau of Xinjiang Uygur Autonomous Region (1997) and Feng (1997) and main focal mechanisms from GCMT (www.globalcmt.org). Largest river outlined, in particular Karakax and Yurunkax river offset (Gaudemer et al., 1989; Ding et al., 2004).

Fig. 2 (a) Western section of Karakax fault along Karakax river loop. Background is Landsat ETM image. (b) Surface rupture map (in red) along Karakax active fault trace. Background are panchromatic SPOT satellite images KJ 204-277 and KJ 205-277 of 24 Sept. 1986 (Peltzer et al., 1989). (c) Detail of Fig. 2b with location of figures.

Fig. 3 (a) View, looking east, towards Sanshiliyingfang (SSYF) city. Surface rupture is particularly clear across alluvial fan surfaces (indicated by the white arrows). (b) Detailed view of rupture across SSYF fan (site 1) with city in background. Note left-lateral offset of fan rim above pave road in foreground.

Fig. 4 Multispectral Ikonos image (pixel size $4 \mathrm{~m}$ ) of the Sanshiliyingfang fan area. 
The fault trace cuts through the Sanshiliyingfang alluvial fan (indicated by the white arrows).

Fig. 5 (a) Ikonos image enhancement of site 1. The surface rupture zone disrupts and offsets all the channels incised at the fan surface. (b) Same as (a) with detailed mapping of rupture strands, and channels and rills. Numbers refer to the sites of offset measurements (Table 2). (c) Distribution of offsets measured across the $2 \mathrm{~km}$-long stretch of the rupture at site 1.

Fig. 6 Offset of western fan margin a site 1. (a) Field view of fan margin offset above paved road. (b) Enlarged Ikonos image and (c) geomorphic interpretation of same area. Several meters high riser is left-laterally offset by several earthquakes. (d) Enlargement of offset area and possible reconstructions of riser top by adjusting piercing lines taking into account their strike and width of fault zone.

Fig. 7 Field views of channel offsets at site 1. Numbers refer to channel numbers (see Fig. 5b, c and Table 2). (a) Example of channels cut by up to 4 sub-parallel rupture strands. Offset is measured across entire fault zone. (b) Offset of a channel where fault is single stranded. (c) $50 \mathrm{~cm}$-deep channel showing cumulative offset of about 18 m. (d) Example of channel cut and offset by multiple fault-strands and where total offset may be estimated as the sum of the offsets across the entire fault zone.

Fig. 8 (a) Multispectral and panchromatic (b) Ikonos image of area of offsets \#14 to 
\#17 (location in Fig. 5b). Fault zone involves several strands that may not be activated simultaneously during same event. Note beheaded channel in northwestern corner previously connected to channel \#14. (c, d) Simplified geomorphic interpretation of image with major fault strands, bottom of channels and risers. (e) Left: smallest 6 to 8 $\mathrm{m}$ offsets identified along channels \#14, \#15 and \#17. Right: Ikonos image reconstruction. (f) Left: cumulative offsets of 13-16 m and 17-21 m of channels \#14 to \#17. Right, top and bottom: Ikonos image reconstruction of these two sets of offsets. (g) Left: largest cumulative offsets of 27 and 28 m of channels \#14-15 and \#17. Right: corresponding Ikonos image reconstruction.

Fig. 9 Multispectral Ikonos image of Karakax valley near site 2. Tributaries of the Karakax river have abandoned sets of fans and terraces across the active Karakax fault. Site 2 is one of these places along the Taersayijilega river, where the number of abandoned terraces is particularly impressive. To the west and east of site 2 , meanders of the Karakax river have obliterated the active fault trace. Farther west, the fault trace can be seen across younger alluvium from the Karakax, a place targeted for paleoseismic trenching.

Fig. 10 Site 2. (a) Panchromatic Ikonos satellite image of Site 2. The south flowing Taersayijilega river has abandoned a set of 5 terrace levels, well preserved on its left bank and all left-laterally offset by the Karakax fault. Blue dots are topographic profiles leveled in the field parallel and perpendicular to average fault strike. (b) 
Geomorphic map of site 2 from field observations and image interpretation. Terrace riser offsets range from $6 \mathrm{~m}$ for the smallest up to $255 \mathrm{~m}$. (c) View towards north of Site 2. Main terraces of Taersayijilega river are cut and offset by Karakax fault scarp (d) Enhancement of field view of left bank terraces at site 2 .

Fig. 11 Map view of the 11 topographic profiles leveled in the field, at site 2 (location in Fig. 10a). (a) Profiles projected N110E parallel to the average strike of the fault. (b) Profiles projected N200E perpendicular to the average strike of the fault.

Fig. 12 (a) Detail of fault trace across Taersayijilega river bed and lower terraces T0 to T2 (Ikonos image). (b) Interpretation of image. River has abandoned the terrace levels that are progressively offset by the fault. Here, the terrace risers are sharp markers of displacement together with channels incised in the terrace surface. (c-h) Progressive reconstruction of terrace risers T0'/T0, T1/T0' and T2/T1 with offset of 6 , 12 and $20 \mathrm{~m}$, respectively. Dotted circles indicate restored marker.

Fig. 13 Field views of terrace risers at site 2. (a) View, looking northwest, from T2. $20 \mathrm{~m}$ offset of T2/T1 riser is outlined. (b) View, looking east, along fault trace from T0. Smallest offset of the youngest riser T0'/T0 amounts about $6 \mathrm{~m}$ and may represent the displacement of the last large earthquake along Karakax fault. The $12 \mathrm{~m}$ offset of next $\mathrm{T} 1 / \mathrm{T} 0$ ' riser may represent the cumulative offset of the 2 last large seismic events. 
Fig. 14 Offsets distribution (b) along $55 \mathrm{~km}$ of western section of Karakax fault between west of Sanxiliyingfang and Kangxiwa (a). Only offsets smaller than $30 \mathrm{~m}$ are represented. Smallest offset values may represent slip from the last large event along the fault (Table 2). See text for discussion.

Fig. 15 Distribution of offsets at site 1 and along $55 \mathrm{~km}$ section (Table 2). Peaks in the probability density curves of the distributions are interpreted as evidence of repeated slip of similar amounts during the last 3 to 4 large events along the fault. Dense offsets distribution at site 1 is enhanced above. Offsets of site 2 are located.

Fig. 16 (a) Ikonos image enhancement of section west of site 2. (b) Enhancement of fault stretch near lower alluvial levels recently deposited near Karakax river bed. Fault is marked by a smooth vertical scarp and the trace of the last earthquakes. Smallest horizontal offset of channels amounts $6 \mathrm{~m}$. Trenching site is located with rectangle.

Fig. 17 (a) View towards north of 3 m-deep trench dug across the fault scarp, near lower alluvial levels of the Karakax river. White rectangle is wall face interpreted in (b). (b) Interpretation of eastern trench wall. Fine grained (silty sands and gravels) sub-horizontal sediment layers are cut, offset or warped by two sets of steeply north dipping fault strands (F1 and F2). F2 faults reach the surface and are interpreted as belonging to the most recent seismic rupture. F1 faults do not propagate to the surface 
and are capped by silty sand, which base is radiocarbon dated at 975-1020 cal. years A.D. Penultimate event must have occurred before 975 cal years AD. Scale is given by meter-spaced white ropes. 


\section{List of tables}

Table 1. List of large earthquakes (Ms $\geq 6)$ in Fig. $1 b$.

Table 2. Geomorphic offsets along $55 \mathrm{~km}$ section of Karakax fault $\left(78^{\circ} \mathrm{E}-78.5^{\circ} \mathrm{E}\right)$

Table 3. Radiocarbon sample from trench along Karakax fault 
Table 1. List of large earthquakes (Ms $\geq 6.0)$ in Figure 1B

\begin{tabular}{|c|c|c|c|c|c|c|}
\hline \multirow[b]{2}{*}{ Local date } & \multicolumn{2}{|c|}{ Epicenter location } & \multirow{2}{*}{$\begin{array}{l}\text { Magnitude } \\
(\mathbf{M s} / \mathbf{M w})^{\circ}\end{array}$} & \multirow{2}{*}{$\begin{array}{l}\text { Depth } \\
(\mathbf{k m})\end{array}$} & \multirow[b]{2}{*}{ Location } & \multirow[b]{2}{*}{ References } \\
\hline & $\begin{array}{c}\text { Latitude } \\
\left({ }^{\circ} \mathbf{N}\right)\end{array}$ & $\begin{array}{c}\text { Longitude } \\
\left({ }^{\circ} \mathbf{E}\right)\end{array}$ & & & & \\
\hline 1882 & 37.0 & 79.5 & 7.0 & & Hetian & SBX* $^{*}, 1997$ \\
\hline 1902.08 .31 & 37.0 & 78.0 & 6.8 & & Pishan & Feng, 1997 \\
\hline 1914.10.09 & 35.0 & 78.0 & 6.5 & & Hetian & Feng, 1997 \\
\hline 1920.10 .12 & 36.0 & 81.0 & 6.3 & & Cele & Feng, 1997 \\
\hline 1924.07 .03 & 36.8 & 83.8 & 7.2 & 33 & Mingfeng & Feng, 1997 \\
\hline 1924.07 .12 & 37.1 & 83.6 & 7.2 & & Mingfeng & Feng, 1997 \\
\hline 1926.08 .07 & 35.4 & 78.7 & 6.5 & & Hetian & Feng, 1997 \\
\hline 1937.11.16 & 35.0 & 78.0 & 6.5 & 100 & Hetian & Feng, 1997 \\
\hline 1948.02 .13 & 36.0 & 80.5 & 6.3 & & Cele & Feng, 1997 \\
\hline 1975.04 .28 & 36.2 & 80.1 & 6.1 & 20 & Hetian & Feng, 1997 \\
\hline 1975.05 .28 & 35.9 & 79.8 & 6.1 & 20 & Keshimier & CENC, 2008 \\
\hline 1975.06 .04 & 36.4 & 80.1 & 6.1 & 31 & Hetian & Feng, 1997 \\
\hline 1992.04 .05 & 36.02 & 81.07 & $5.9(\mathrm{Mw} 5.7)$ & 28 & Cele & SBX, 1997 \\
\hline 1996.11 .19 & 35.78 & 78.3 & $7.1(\mathrm{Mw} 6.8)$ & & Kalakun pass & $\mathrm{SBX}^{\#}, 2008$ \\
\hline 1998.05 .29 & 37.8 & & $6.2(\mathrm{Mw} 5.6)$ & & Hetian & SBX, 2008 \\
\hline 2008.03 .21 & 35.61 & 81.11 & 6.2 & 15 & Cele & CENC, 2008 \\
\hline 2008.03 .21 & 35.445 & 81.392 & $7.3(\mathrm{Mw} 7.1)$ & 14 & Cele & USGS, 2008 \\
\hline
\end{tabular}

*Seismological Bureau of Xinjiang Uygur Autonomous Region (SBX). Instruction of Xinjiang Uygur Autonomous Region seismotectonic map (1:2000000). Chengdu; Chengdu Map Publishing House, 1997 \#Seismological Bureau of Xinjiang Uygur Autonomous Region (SBX), Catalog for earthquakes in Xinjiang (1970 2000), 2008.

${ }^{\circ}$ Magnitude Ms before 1992, moment magnitude Mw from GCMT. 
Table 2. Geomorphic offsets along $55 \mathrm{~km}$ section of Karakax fault $\left(7^{\circ} \mathrm{E}-78.5^{\circ} \mathrm{E}\right)$

\begin{tabular}{|c|c|c|c|c|c|c|c|c|c|}
\hline $\begin{array}{c}\text { Number } \\
\text { (see Fig. 5) }\end{array}$ & $\begin{array}{c}\text { Position } \\
\text { (Longitude }{ }^{\circ} \mathrm{E} \text { ) }\end{array}$ & $\begin{array}{c}\text { Distance from } \\
78^{\circ} \mathrm{E}(\mathrm{m})\end{array}$ & $\begin{array}{c}\text { Offset } \\
(\mathrm{m})\end{array}$ & $\begin{array}{c}\text { Position } \\
\left(\text { Longitude }{ }^{\circ} \mathrm{E}\right)\end{array}$ & $\begin{array}{c}\text { Distance from } \\
78^{\circ} \mathrm{E}(\mathrm{m})\end{array}$ & $\begin{array}{l}\text { Offset } \\
(\mathrm{m})\end{array}$ & $\begin{array}{c}\text { Position } \\
\left(\text { Longitude }{ }^{\circ} \mathrm{E}\right)\end{array}$ & $\begin{array}{c}\text { Distance from } \\
78^{\circ} \mathrm{E}(\mathrm{m})\end{array}$ & $\begin{array}{l}\text { Offset } \\
(\mathrm{m})\end{array}$ \\
\hline & $77^{\circ} 59^{\prime} 33,61$ & -656 & $6 \pm 1$ & $78^{\circ} 03^{\prime} 40,22$ & 5475 & $32 \pm 2$ & $78^{\circ} 20^{\prime} 31,37$ & 30616 & $10 \pm 1$ \\
\hline & $77^{\circ} 59^{\prime} 40,61$ & -482 & $18 \pm 2$ & $78^{\circ} 04^{\prime} 45,90$ & 7109 & $14 \pm 1$ & $78^{\circ} 20^{\prime} 38,55$ & 30795 & $19 \pm 2$ \\
\hline 1 & $78^{\circ} 00^{\prime} 21.80$ & 542 & $24 \pm 6$ & $78^{\circ} 04^{\prime} 49,01$ & 7186 & $6 \pm 1$ & $78^{\circ} 21^{\prime} 03,06$ & 31404 & $7 \pm 1$ \\
\hline 2 & $78^{\circ} 00^{\prime} 27.89$ & 693 & $14 \pm 1$ & $78^{\circ} 04^{\prime} 49,56$ & 7200 & $33 \pm 2$ & $78^{\circ} 21^{\prime} 25,93$ & 31973 & $19 \pm 1$ \\
\hline 3 & $78^{\circ} 00^{\prime} 33.91$ & 843 & $28 \pm 2$ & $78^{\circ} 05^{\prime} 10,86$ & 7729 & $6 \pm 1$ & $78^{\circ} 21^{\prime} 36,23$ & 32229 & $8 \pm 1$ \\
\hline 3 & $\sim 78^{\circ} 00^{\prime} 34.26$ & 852 & $23 \pm 2$ & $78^{\circ} 05^{\prime} 14,62$ & 7823 & $12 \pm 1$ & $78^{\circ} 21^{\prime} 36,95$ & 32247 & $140 \pm 5$ \\
\hline 4 & $78^{\circ} 00^{\prime} 36.73$ & 913 & $23 \pm 2$ & $78^{\circ} 05^{\prime} 16,71$ & 7875 & $20 \pm 2$ & $78^{\circ} 21^{\prime} 44,92$ & 32445 & $220 \pm 10$ \\
\hline 4 & $78^{\circ} 00^{\prime} 37.24$ & 926 & $13 \pm 1$ & $78^{\circ} 05^{\prime} 24,42$ & 8066 & $195 \pm 5$ & $78^{\circ} 22^{\prime} 01,24$ & 32851 & $19 \pm 1$ \\
\hline 4 & $\sim 78^{\circ} 00^{\prime} 37.60$ & 935 & $10 \pm 1$ & $78^{\circ} 05^{\prime} 29,18$ & 8185 & $250 \pm 10$ & $78^{\circ} 22^{\prime} 25,48$ & 33454 & $4 \pm 1$ \\
\hline 4 & $78^{\circ} 00^{\prime} 39.06$ & 971 & $15 \pm 1$ & $78^{\circ} 05^{\prime} 33,06$ & 8281 & $255 \pm 20$ & $78^{\circ} 22^{\prime} 46,42$ & 33974 & $6 \pm 1$ \\
\hline 5 & $\sim 78^{\circ} 00^{\prime} 39.46$ & 981 & $18 \pm 2$ & $78^{\circ} 06^{\prime} 28,46$ & 9659 & $5 \pm 1$ & $78^{\circ} 23^{\prime} 02,13$ & 34365 & $8 \pm 1$ \\
\hline 6 & $78^{\circ} 00^{\prime} 40.74$ & 1013 & $8 \pm 1$ & $78^{\circ} 06^{\prime} 38,96$ & 9920 & $14 \pm 1$ & $78^{\circ} 23^{\prime} 17,01$ & 34735 & $5 \pm 1$ \\
\hline 6 & $78^{\circ} 00^{\prime} 41.28$ & 1026 & $7 \pm 2$ & $78^{\circ} 06^{\prime} 56,57$ & 10357 & $8 \pm 1$ & $78^{\circ} 23^{\prime} 30,23$ & 35064 & $6 \pm 1$ \\
\hline 7 & $78^{\circ} 00^{\prime} 44.75$ & 1113 & $8 \pm 1$ & $78^{\circ} 08^{\prime} 12,63$ & 12249 & $6 \pm 1$ & $78^{\circ} 24^{\prime} 03,20$ & 35883 & $3 \pm 1$ \\
\hline 8 & $78^{\circ} 00^{\prime} 46.22$ & 1149 & $8 \pm 1$ & $78^{\circ} 08^{\prime} 34,76$ & 12799 & $5 \pm 1$ & $78^{\circ} 24^{\prime} 49,90$ & 37044 & $9 \pm 1$ \\
\hline 9 & $78^{\circ} 00^{\prime} 46.99$ & 1168 & $19 \pm 2$ & $78^{\circ} 08^{\prime} 56,55$ & 13341 & $7 \pm 1$ & $78^{\circ} 25^{\prime} 27,46$ & 37978 & $5 \pm 1$ \\
\hline 10 & $78^{\circ} 00^{\prime} 47.54$ & 1182 & $8 \pm 1$ & $78^{\circ} 09^{\prime} 11,05$ & 13701 & $8 \pm 1$ & $78^{\circ} 25^{\prime} 34,03$ & 38142 & $90 \pm 5$ \\
\hline 11 & $78^{\circ} 00^{\prime} 50.20$ & 1248 & $7 \pm 1$ & $78^{\circ} 09^{\prime} 21,12$ & 13952 & $9 \pm 1$ & $78^{\circ} 25^{\prime} 34,84$ & 38162 & $3 \pm 1$ \\
\hline 12 & $78^{\circ} 00^{\prime} 53.43$ & 1328 & $8 \pm 1$ & $78^{\circ} 09^{\prime} 50,87$ & 14691 & $9 \pm 1$ & $78^{\circ} 25^{\prime} 35,26$ & 38172 & $12 \pm 1$ \\
\hline 12 & $\sim 78^{\circ} 00^{\prime} 53.95$ & 1341 & $10 \pm 2$ & $78^{\circ} 10^{\prime} 51,09$ & 16189 & $13 \pm 1$ & $78^{\circ} 25^{\prime} 36,01$ & 38191 & $24 \pm 2$ \\
\hline 13 & $78^{\circ} 00^{\prime} 54.74$ & 1361 & $10 \pm 2$ & $78^{\circ} 10^{\prime} 55,83$ & 16306 & $7 \pm 1$ & $78^{\circ} 25^{\prime} 36,10$ & 38193 & $34 \pm 2$ \\
\hline 14 & $78^{\circ} 00^{\prime} 56.61$ & 1408 & $6 \pm 1$ & $78^{\circ} 11^{\prime} 44,92$ & 17527 & $5 \pm 1$ & $78^{\circ} 25^{\prime} 36,81$ & 38211 & $50 \pm 5$ \\
\hline 14 & $\sim 78^{\circ} 00^{\prime} 56.90$ & 1415 & $20 \pm 2$ & $78^{\circ} 12^{\prime} 06,23$ & 18057 & $3 \pm 1$ & $78^{\circ} 26^{\prime} 03,56$ & 38876 & $5 \pm 1$ \\
\hline 15 & $\sim 78^{\circ} 00^{\prime} 57.77$ & 1436 & $8 \pm 2$ & $78^{\circ} 12^{\prime} 52,73$ & 19213 & $6 \pm 1$ & $78^{\circ} 26^{\prime} 41,84$ & 39828 & $5 \pm 1$ \\
\hline 15 & $78^{\circ} 00^{\prime} 58.24$ & 1448 & $17 \pm 2$ & $78^{\circ} 14^{\prime} 22,68$ & 21449 & $6 \pm 1$ & $78^{\circ} 26^{\prime} 56,45$ & 40191 & $3 \pm 1$ \\
\hline 15 & $78^{\circ} 00^{\prime} 58.24$ & 1448 & $27 \pm 3$ & $78^{\circ} 15^{\prime} 05,67$ & 22518 & $5 \pm 1$ & $78^{\circ} 27^{\prime} 16,8$ & 40697 & $10 \pm 2$ \\
\hline 16 & $\sim 78^{\circ} 00^{\prime} 58.62$ & 1458 & $16 \pm 2$ & $78^{\circ} 15^{\prime} 33,01$ & 23198 & $3 \pm 1$ & $78^{\circ} 27^{\prime} 22,99$ & 40851 & $4 \pm 1$ \\
\hline 16 & $\sim 78^{\circ} 00^{\prime} 58.62$ & 1458 & $19 \pm 2$ & $78^{\circ} 15^{\prime} 48,77$ & 23590 & $4 \pm 1$ & $78^{\circ} 27^{\prime} 40,64$ & 41290 & $5 \pm 1$ \\
\hline 17 & $78^{\circ} 01^{\prime} 00.96$ & 1516 & $8 \pm 1$ & $78^{\circ} 16^{\prime} 22,13$ & 24419 & $6 \pm 1$ & $78^{\circ} 28^{\prime} 10,47$ & 42031 & $4 \pm 1$ \\
\hline 17 & $78^{\circ} 01^{\prime} 00.96$ & 1516 & $17 \pm 2$ & $78^{\circ} 16^{\prime} 34,99$ & 24739 & $11 \pm 1$ & $78^{\circ} 28^{\prime} 15,49$ & 42156 & $5 \pm 1$ \\
\hline 17 & $78^{\circ} 01^{\prime} 00.96$ & 1516 & $28 \pm 3$ & $78^{\circ} 16^{\prime} 37,71$ & 24807 & $22 \pm 2$ & $78^{\circ} 28^{\prime} 31,51$ & 42554 & $4 \pm 1$ \\
\hline 18 & $78^{\circ} 01^{\prime} 03.03$ & 1567 & $8 \pm 1$ & $78^{\circ} 16^{\prime} 45,26$ & 24994 & $5 \pm 1$ & $78^{\circ} 28^{\prime} 56,11$ & 43166 & $4 \pm 1$ \\
\hline 19 & $78^{\circ} 01^{\prime} 04.13$ & 1595 & $8 \pm 1$ & $78^{\circ} 16^{\prime} 48,65$ & 25079 & $140 \pm 5$ & $78^{\circ} 29^{\prime} 35,40$ & 44143 & $5 \pm 1$ \\
\hline 20 & $78^{\circ} 01^{\prime} 05.12$ & 1619 & $9 \pm 1$ & $78^{\circ} 16^{\prime} 53,02$ & 25187 & $248 \pm 10$ & $78^{\circ} 29^{\prime} 54,47$ & 44617 & $5 \pm 1$ \\
\hline 20 & $78^{\circ} 01^{\prime} 05.12$ & 1619 & $16 \pm 2$ & $78^{\circ} 17^{\prime} 50,43$ & 26615 & $4 \pm 1$ & $78^{\circ} 29^{\prime} 68,52$ & 44967 & $130 \pm 10$ \\
\hline 20 & $78^{\circ} 01^{\prime} 05.53$ & 1629 & $19 \pm 1$ & $78^{\circ} 17^{\prime} 52,97$ & 26678 & $12 \pm 1$ & $78^{\circ} 30^{\prime} 15,19$ & 45132 & $4 \pm 1$ \\
\hline 21 & $78^{\circ} 01^{\prime} 05.78$ & 1636 & $13 \pm 1$ & $78^{\circ} 18^{\prime} 17,62$ & 27291 & $42 \pm 4$ & $78^{\circ} 30^{\prime} 19,09$ & 45229 & $6 \pm 1$ \\
\hline 21 & $\sim 78^{\circ} 01^{\prime} 06.08$ & 1643 & $11 \pm 1$ & $78^{\circ} 18^{\prime} 18,59$ & 27315 & $17 \pm 2$ & $78^{\circ} 30^{\prime} 45,92$ & 45896 & $9 \pm 1$ \\
\hline 21 & $\sim 78^{\circ} 01^{\prime} 06.28$ & 1648 & $21 \pm 2$ & $78^{\circ} 18^{\prime} 20,88$ & 27372 & $7 \pm 1$ & $78^{\circ} 30^{\prime} 64,20$ & 46351 & $120 \pm 10$ \\
\hline 21 & $78^{\circ} 01^{\prime} 06.46$ & 1652 & $25 \pm 2$ & $78^{\circ} 18^{\prime} 23,48$ & 27437 & $7 \pm 1$ & $78^{\circ} 31^{\prime} 23,69$ & 46836 & $6 \pm 1$ \\
\hline 22 & $78^{\circ} 01^{\prime} 07.18$ & 1670 & $10 \pm 1$ & $78^{\circ} 18^{\prime} 25,16$ & 27478 & $8 \pm 1$ & $78^{\circ} 31^{\prime} 47,03$ & 47416 & $8 \pm 1$ \\
\hline 23 & $\sim 78^{\circ} 01^{\prime} 08.24$ & 1697 & $8 \pm 1$ & $78^{\circ} 18^{\prime} 25,86$ & 27496 & $8 \pm 1$ & $78^{\circ} 32^{\prime} 04,16$ & 47842 & $3 \pm 1$ \\
\hline 24 & $\sim 78^{\circ} 01^{\prime} 09.21$ & 1721 & $7 \pm 1$ & $78^{\circ} 18^{\prime} 26,09$ & 27501 & $6 \pm 1$ & $78^{\circ} 32^{\prime} 34,00$ & 48584 & $4 \pm 1$ \\
\hline 25 & $78^{\circ} 01^{\prime} 10.14$ & 1744 & $10 \pm 2$ & $78^{\circ} 18^{\prime} 26,56$ & 27513 & $6 \pm 1$ & $78^{\circ} 32^{\prime} 35,33$ & 48617 & $6 \pm 1$ \\
\hline 26 & $78^{\circ} 01^{\prime} 12.29$ & 1797 & $10 \pm 1$ & $78^{\circ} 18^{\prime} 28,85$ & 27570 & $69 \pm 5$ & $78^{\circ} 32^{\prime} 38,37$ & 48692 & $16 \pm 2$ \\
\hline 27 & $78^{\circ} 01^{\prime} 12.85$ & 1811 & $9 \pm 1$ & $78^{\circ} 18^{\prime} 32,11$ & 27651 & $8 \pm 1$ & $78^{\circ} 33^{\prime} 23,60$ & 49817 & $9 \pm 1$ \\
\hline 28 & $78^{\circ} 01^{\prime} 13.36$ & 1824 & $9 \pm 1$ & $78^{\circ} 18^{\prime} 32,65$ & 27665 & $8 \pm 1$ & $78^{\circ} 33^{\prime} 24,18$ & 49831 & $16 \pm 1$ \\
\hline \multirow[t]{11}{*}{29} & $78^{\circ} 01^{\prime} 15.48$ & 1877 & $6 \pm 1$ & $78^{\circ} 18^{\prime} 35,07$ & 27725 & $21 \pm 2$ & $78^{\circ} 33^{\prime} 32,26$ & 50032 & $4 \pm 1$ \\
\hline & $78^{\circ} 02^{\prime} 26,5$ & 3643 & $6 \pm 2$ & $78^{\circ} 18^{\prime} 43,55$ & 27936 & $8 \pm 1$ & $78^{\circ} 33^{\prime} 41,06$ & 50251 & $7 \pm 1$ \\
\hline & $78^{\circ} 02^{\prime} 27,1$ & 3657 & $8 \pm 1$ & $78^{\circ} 18^{\prime} 43,89$ & 27944 & $8 \pm 1$ & $78^{\circ} 33^{\prime} 42,27$ & 50281 & $13 \pm 1$ \\
\hline & $78^{\circ} 02^{\prime} 28,2$ & 3685 & $7 \pm 1$ & $78^{\circ} 19^{\prime} 01,07$ & 28371 & $45 \pm 5$ & $78^{\circ} 33^{\prime} 42,68$ & 50291 & $13 \pm 1$ \\
\hline & $78^{\circ} 02^{\prime} 29,32$ & 3713 & $5 \pm 1$ & $78^{\circ} 19^{\prime} 01,47$ & 28381 & $69 \pm 5$ & $78^{\circ} 33^{\prime} 44,99$ & 50349 & $130 \pm 5$ \\
\hline & $78^{\circ} 03^{\prime} 14,39$ & 4833 & $6 \pm 1$ & $78^{\circ} 19^{\prime} 07,16$ & 28523 & $5 \pm 1$ & $78^{\circ} 34^{\prime} 02,87$ & 50793 & $7 \pm 1$ \\
\hline & $78^{\circ} 03^{\prime} 20,97$ & 4997 & $4 \pm 1$ & $78^{\circ} 19^{\prime} 24,18$ & 28946 & $6 \pm 1$ & $78^{\circ} 34^{\prime} 05,61$ & 50861 & $3 \pm 1$ \\
\hline & $78^{\circ} 03^{\prime} 32,80$ & 5291 & $6 \pm 1$ & $78^{\circ} 19^{\prime} 41,01$ & 29364 & $8 \pm 1$ & $78^{\circ} 34^{\prime} 13,16$ & 51049 & $15 \pm 1$ \\
\hline & $78^{\circ} 03^{\prime} 33,40$ & 5306 & $14 \pm 1$ & $78^{\circ} 19^{\prime} 57,43$ & 29773 & $17 \pm 2$ & $78^{\circ} 34^{\prime} 16,97$ & 51144 & $130 \pm 5$ \\
\hline & $78^{\circ} 03^{\prime} 33,90$ & 5318 & $32 \pm 2$ & $78^{\circ} 20^{\prime} 16,39$ & 30244 & $7 \pm 1$ & $78^{\circ} 34^{\prime} 27,25$ & 51399 & $21 \pm 2$ \\
\hline & $78^{\circ} 03^{\prime} 38,95$ & 5444 & $45 \pm 5$ & $78^{\circ} 20^{\prime} 29,27$ & 30564 & $10 \pm 1$ & & & \\
\hline
\end{tabular}


Table 3. Radiocarbon sample from trench along Karakax fault

\begin{tabular}{|c|c|c|c|c|}
\hline Complo & Complo & I ohorotony & Dodionthon & Calendar age $^{\circ}$ \\
\hline number & material & number & (years BP)\# & $2 \sigma(95.4 \%)$ \\
\hline WKL05-2 & $\begin{array}{l}\text { Carbon } \\
\text { debris }\end{array}$ & BA05992* & $1050 \pm 30$ & $\begin{array}{l}\text { 890AD }(10.8 \%) 920 \mathrm{AD} \\
940 \mathrm{AD}(84.6 \%) 1030 \mathrm{AD}\end{array}$ \\
\hline
\end{tabular}

*AMS Laboratory, School of archaeology and museology, Peking University

\#Half-life of radiocarbon is 5568 years.

${ }^{\circ}$ Calculated using OxCal v3.10 (Christopher, 2005) and tree-ring correction curve from InCal04 (Reimer et al., 2004). 

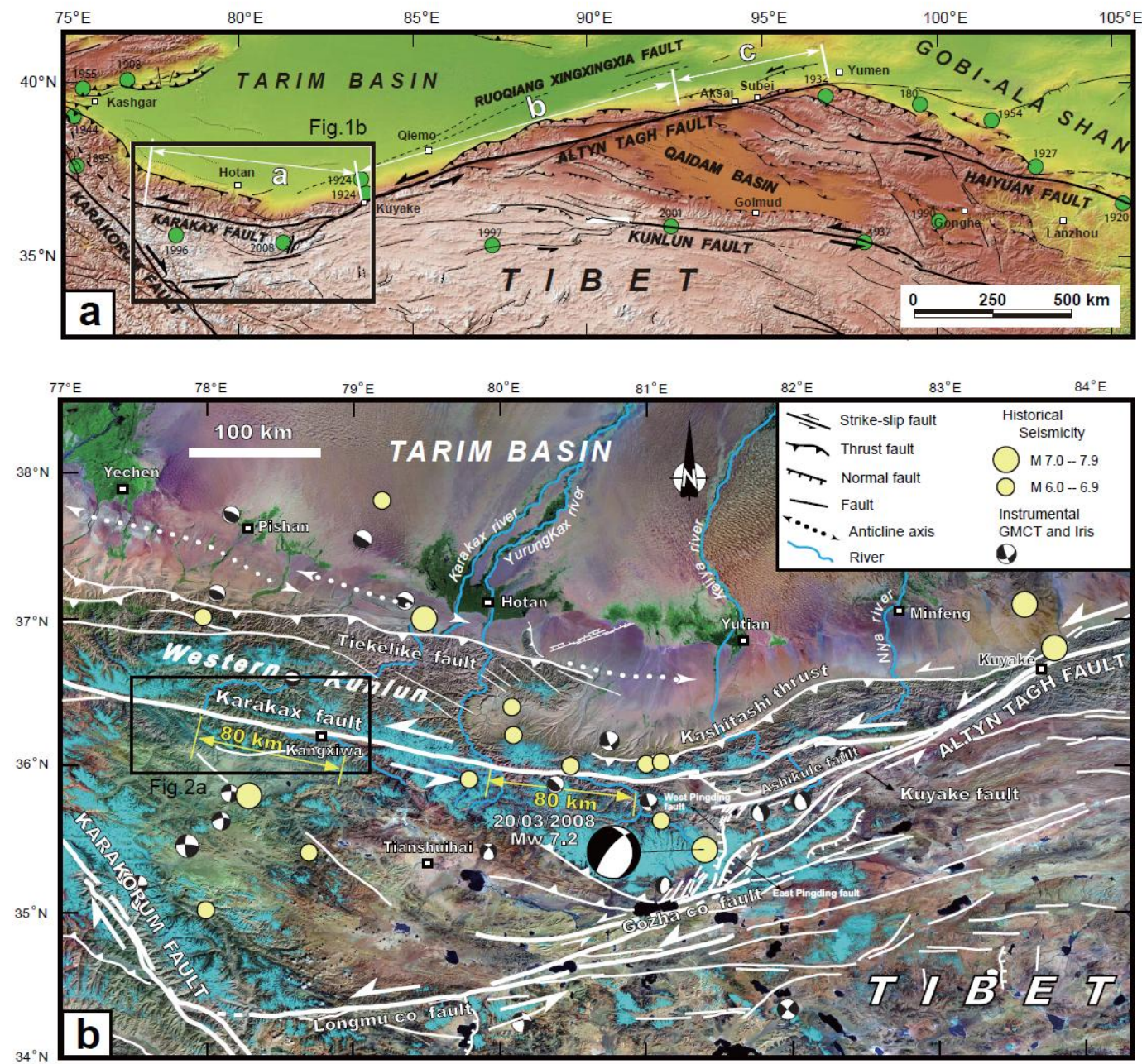

Li, H., et al. - Figure 1 

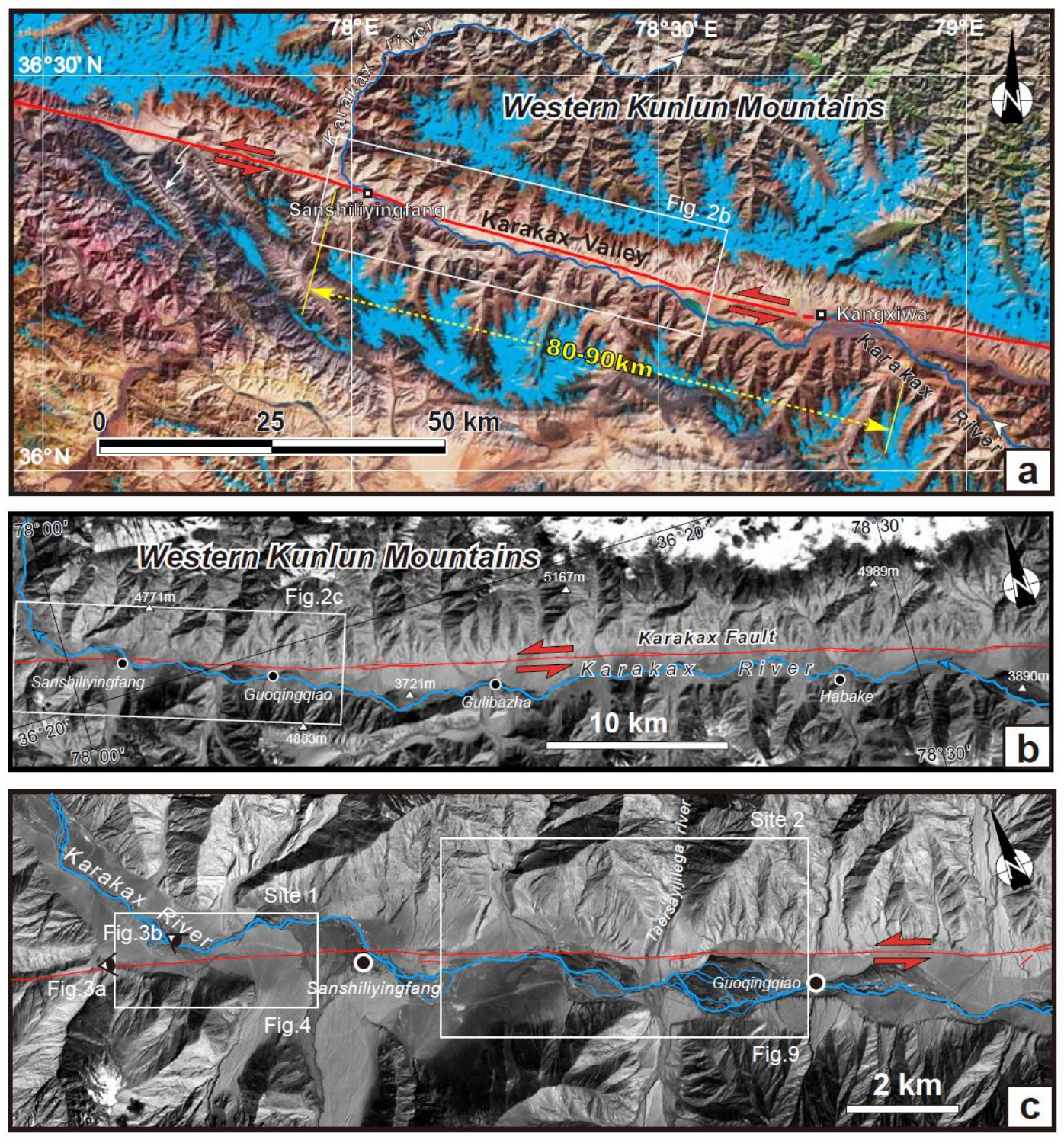

Li, H., et al. - Figure 2 

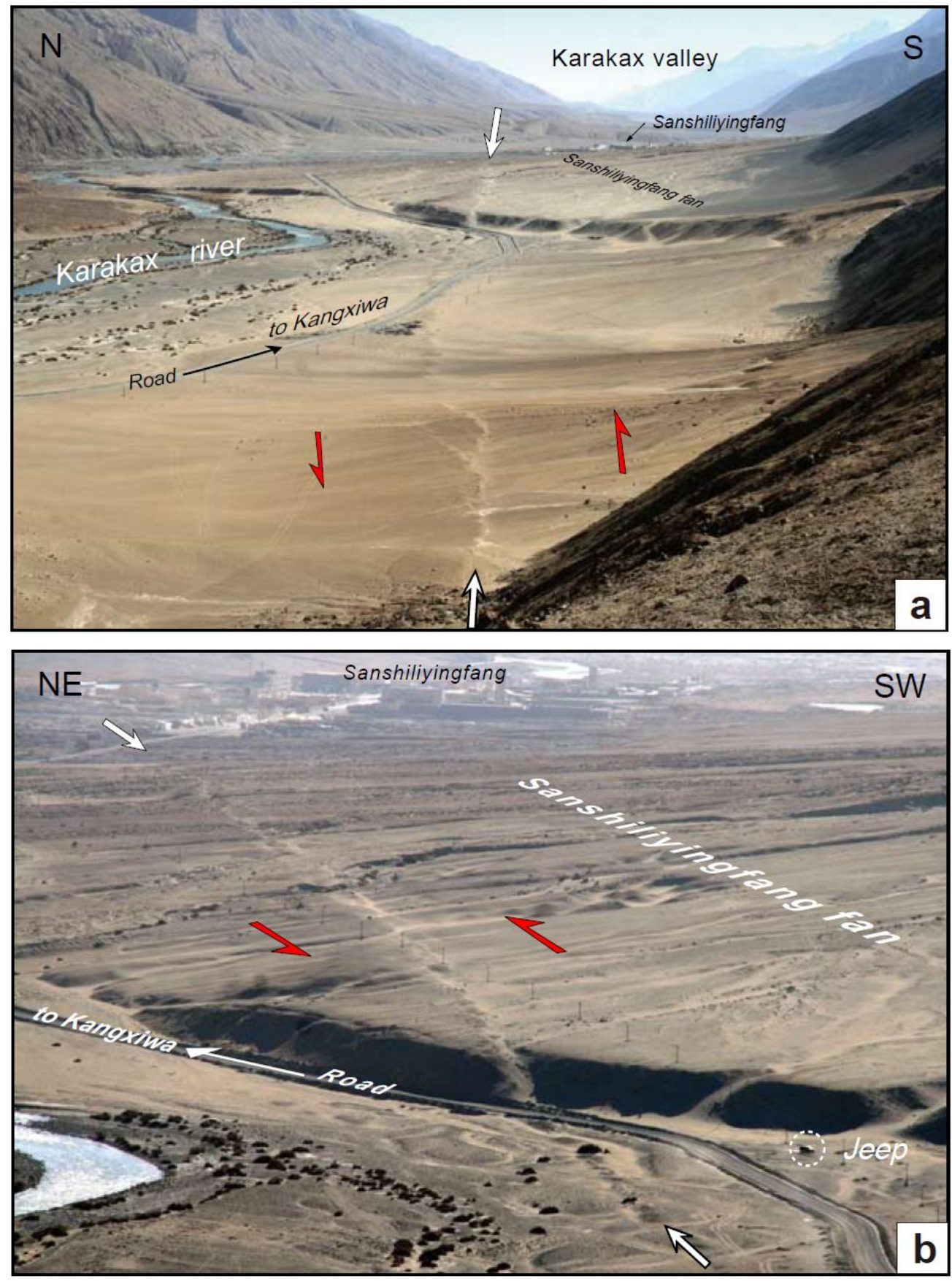

Li H. et al., Figure 3 


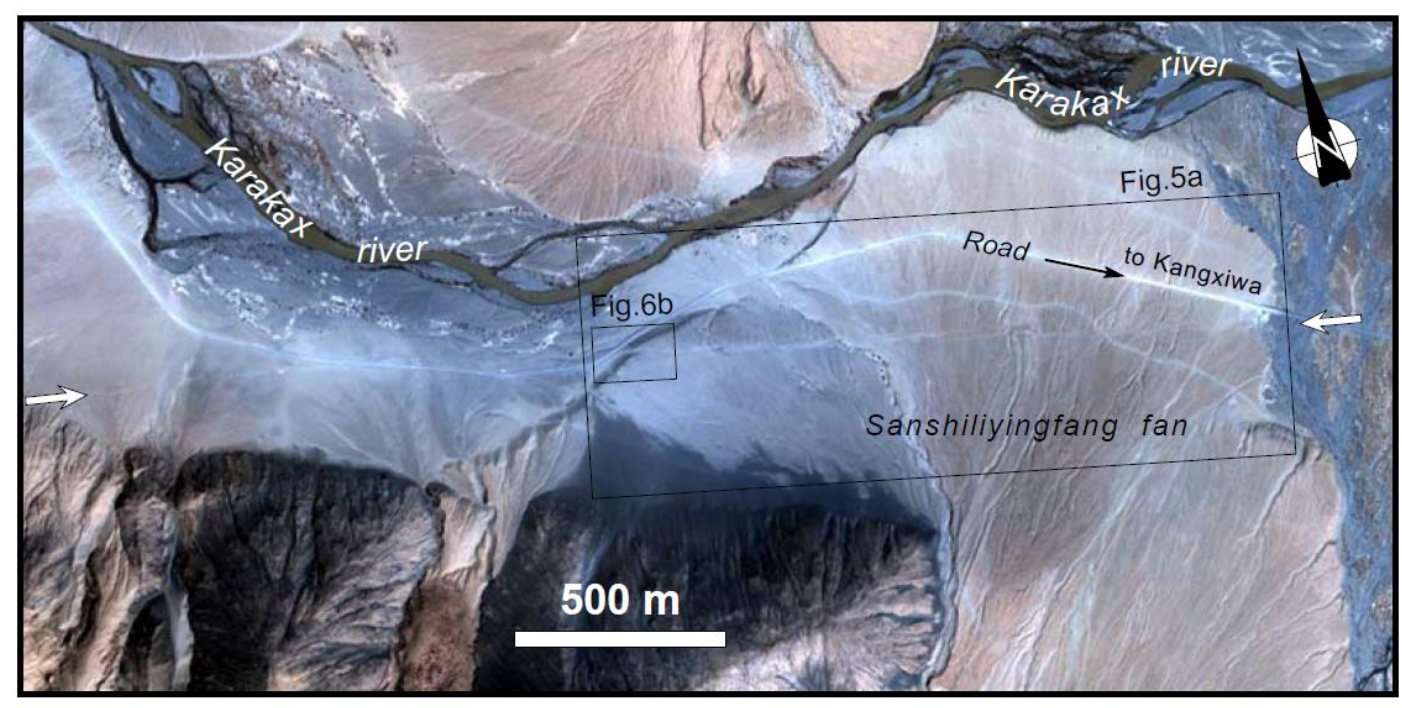

Li, H. et al.,-Figure 4 

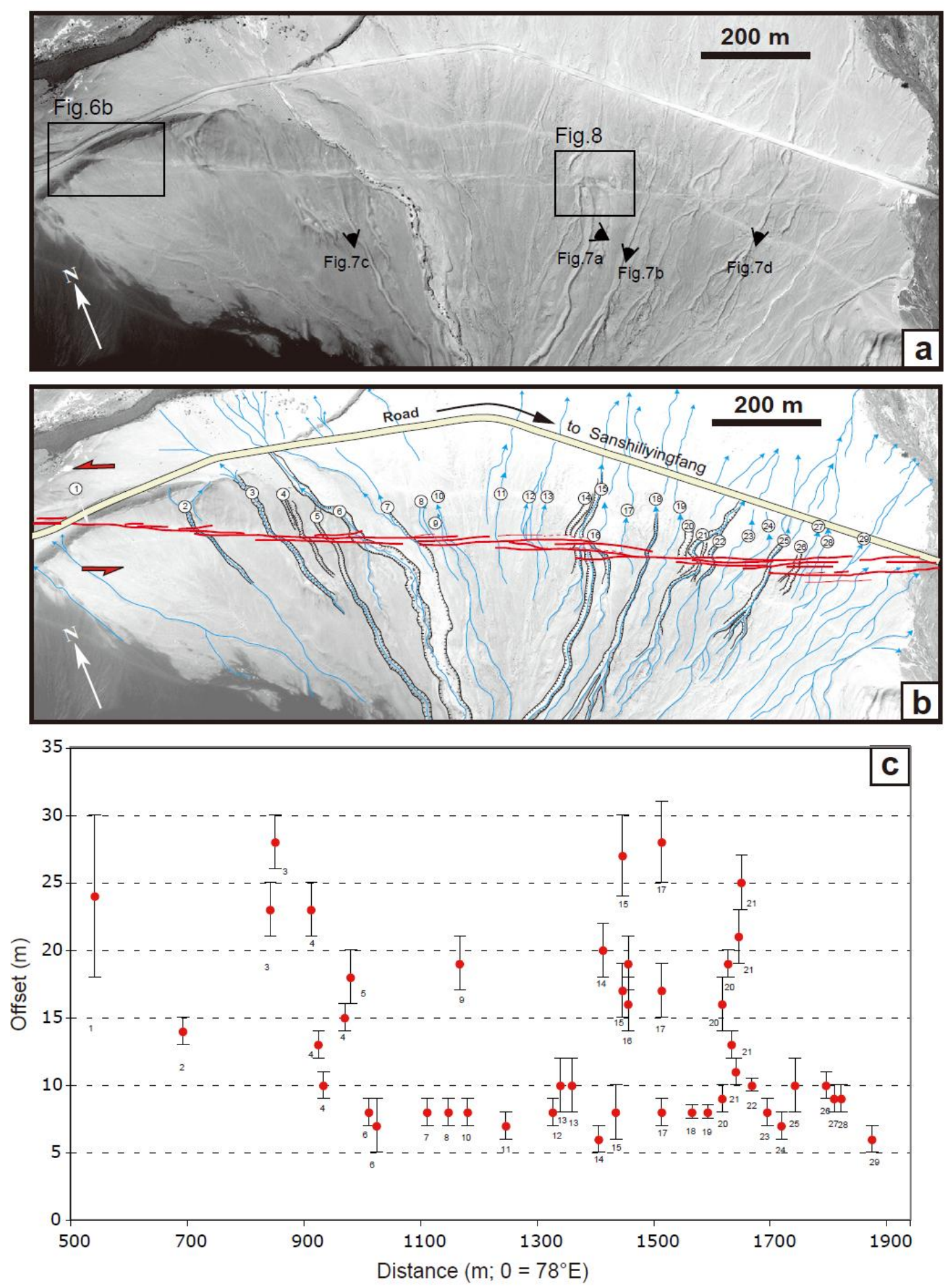

Li, H., et al. - Figure 5 

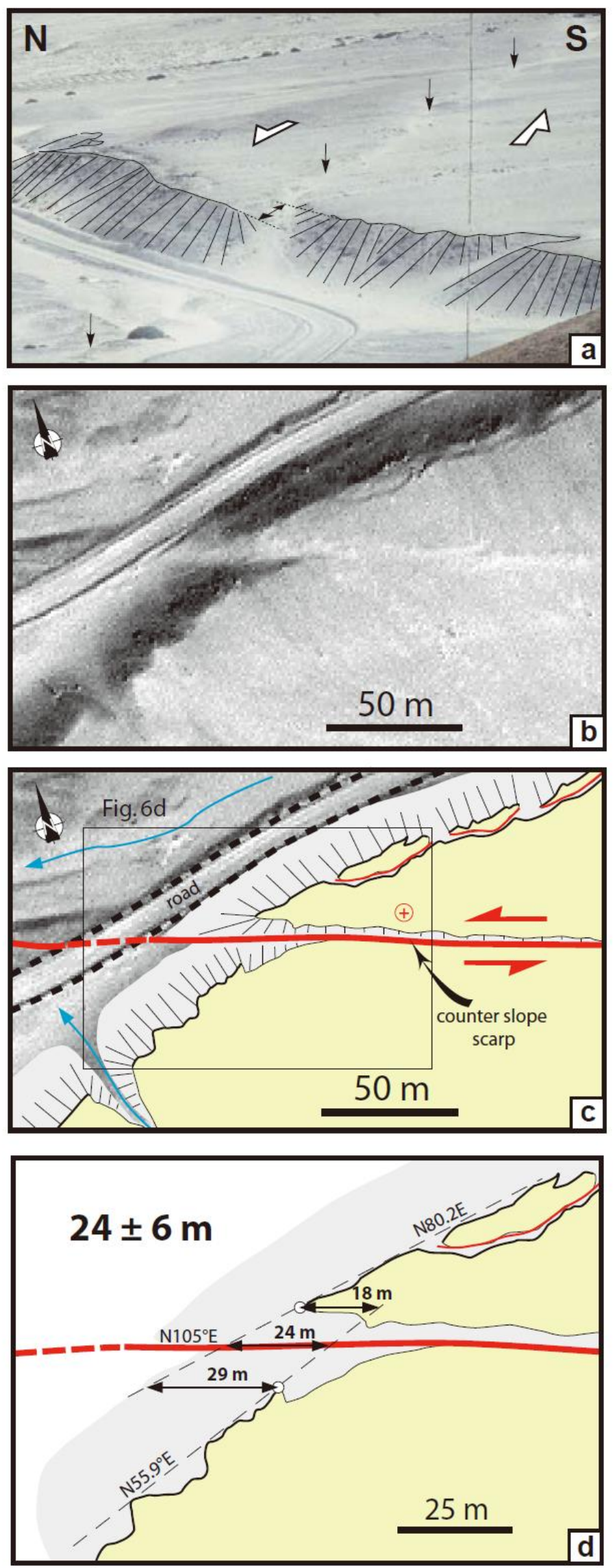

Li, H., et al. - Figure 6 


\section{ACCEPTED MANUSCRIPT}
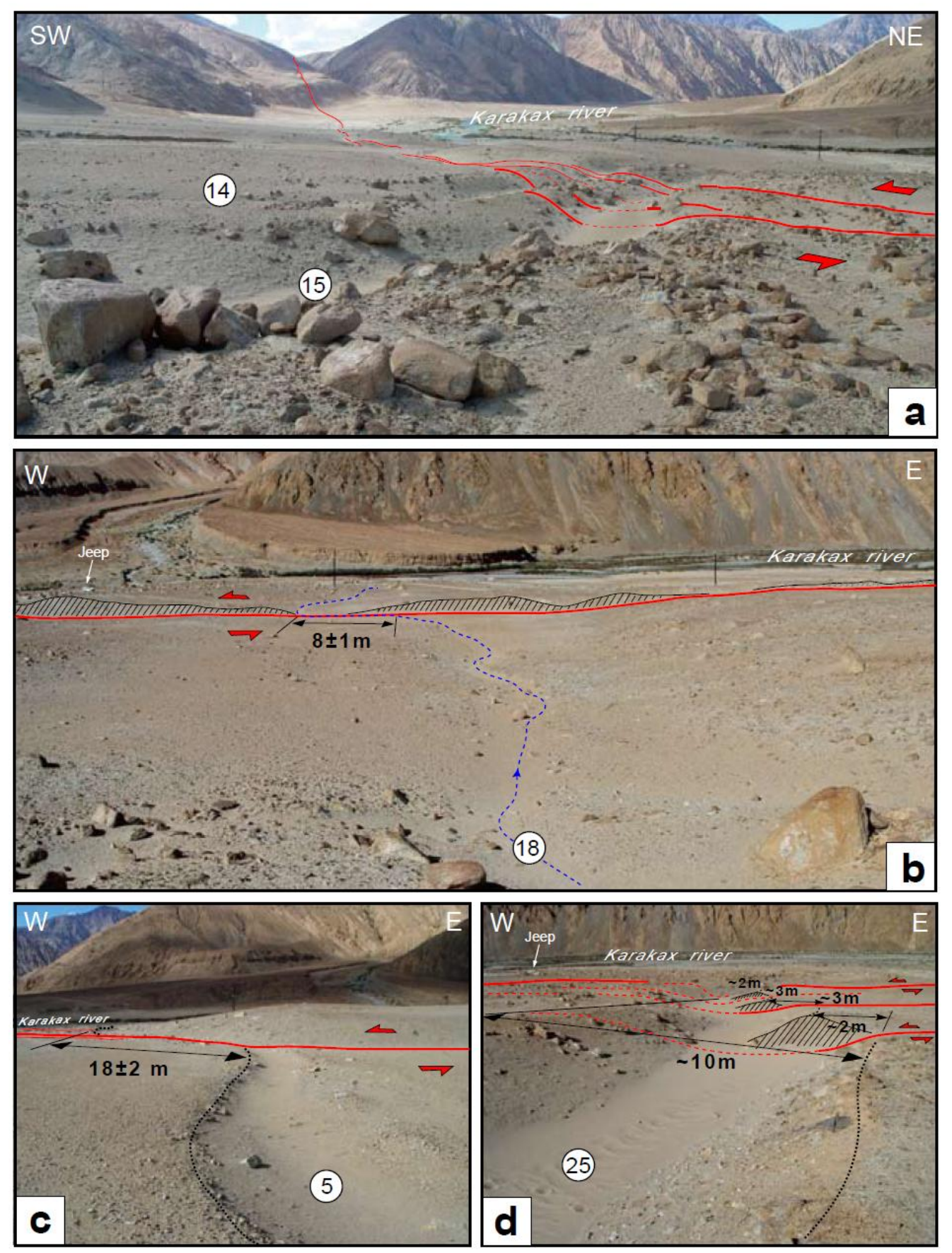

Li, H. et al.,-Figure 7 

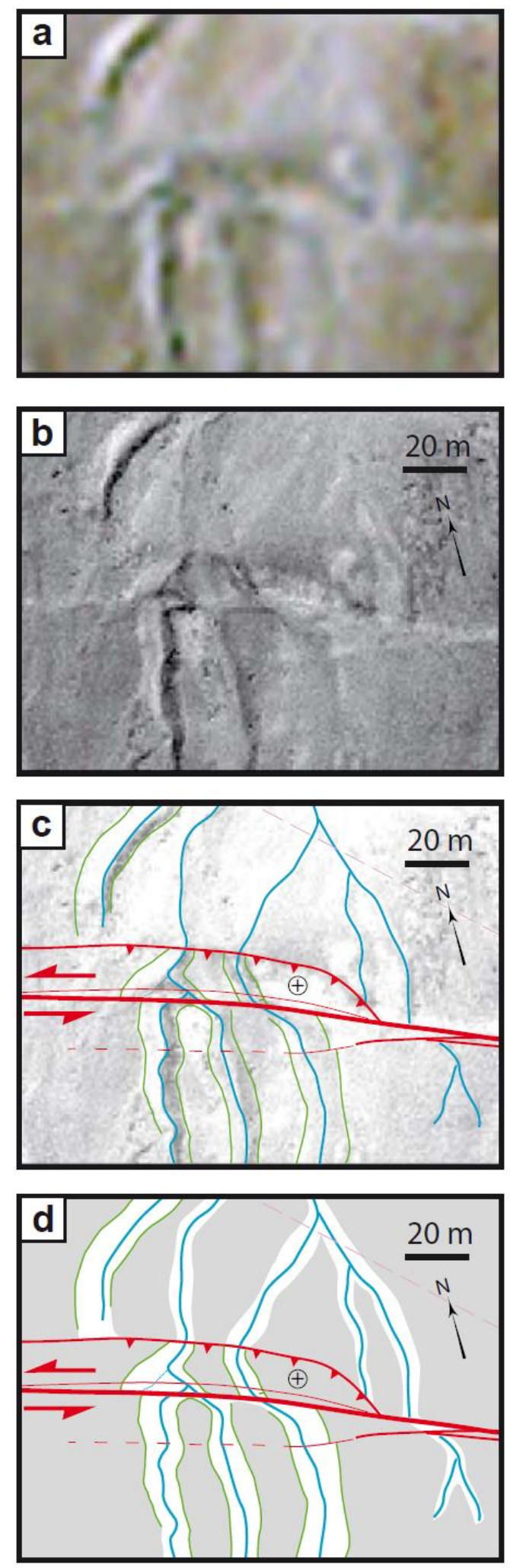

Li, H. et al. - Figure 8 a-d 

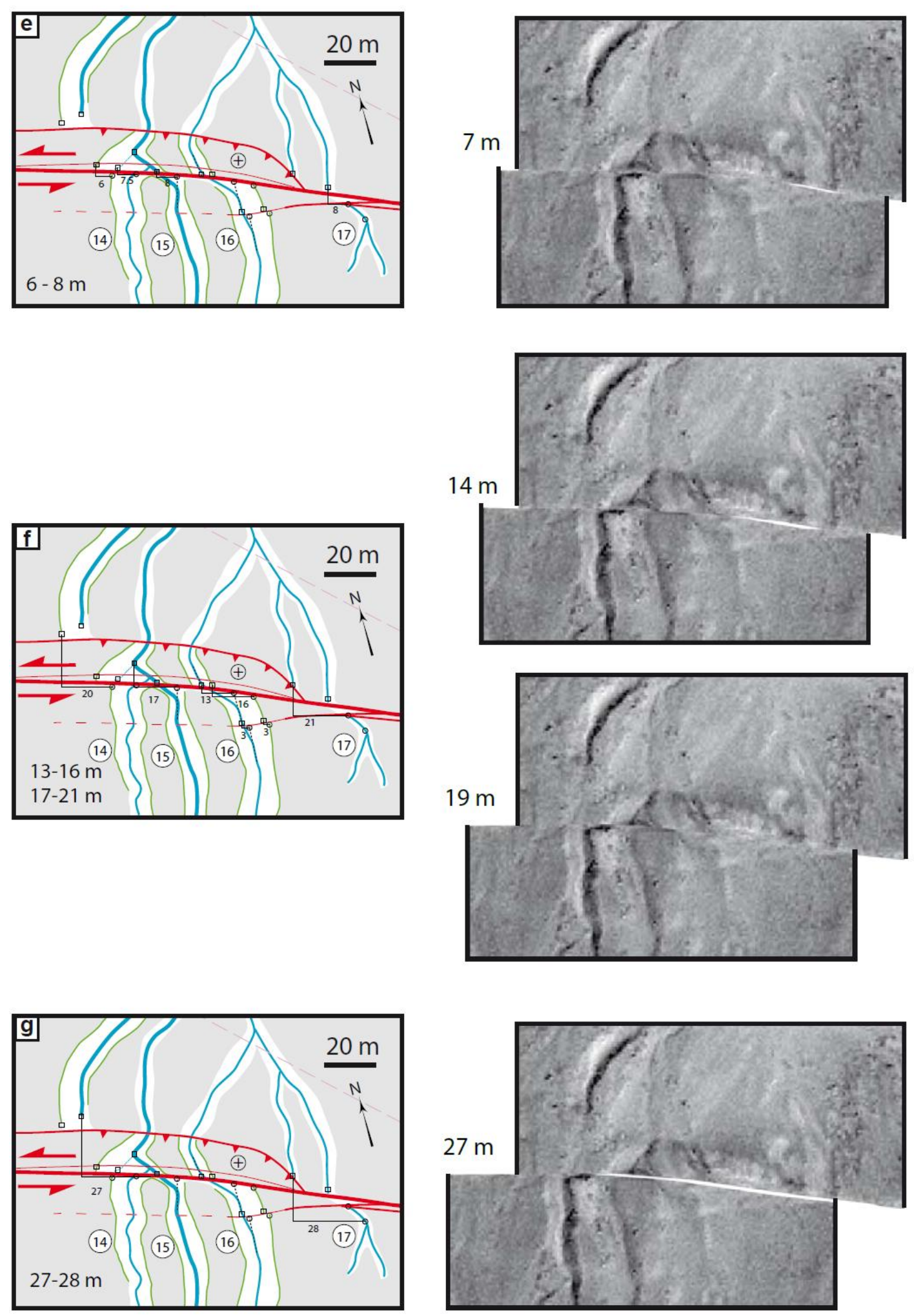

Li, H. et al. - Figure 8 e-g 


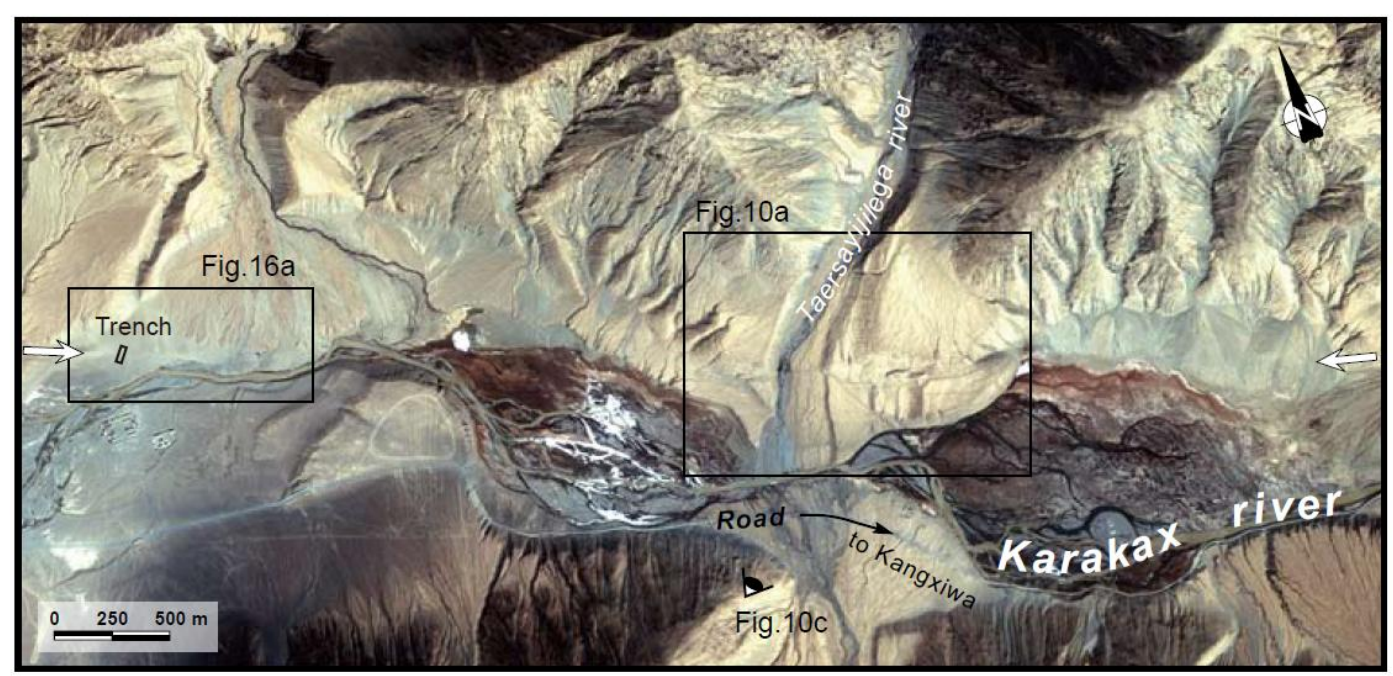

Li, H. et al.,-Figure 9 

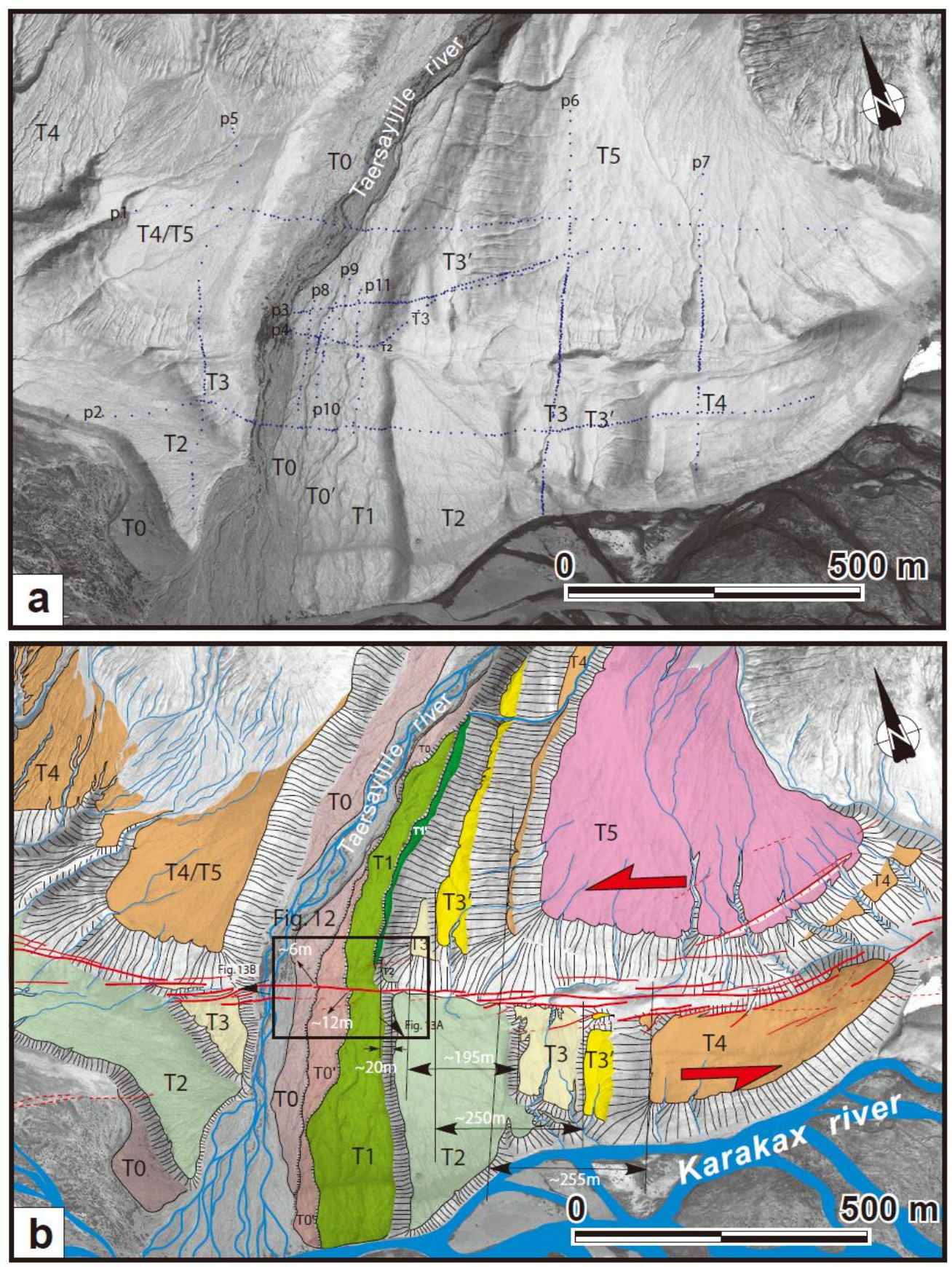

Li, H., et al. - Figure 10a,b 

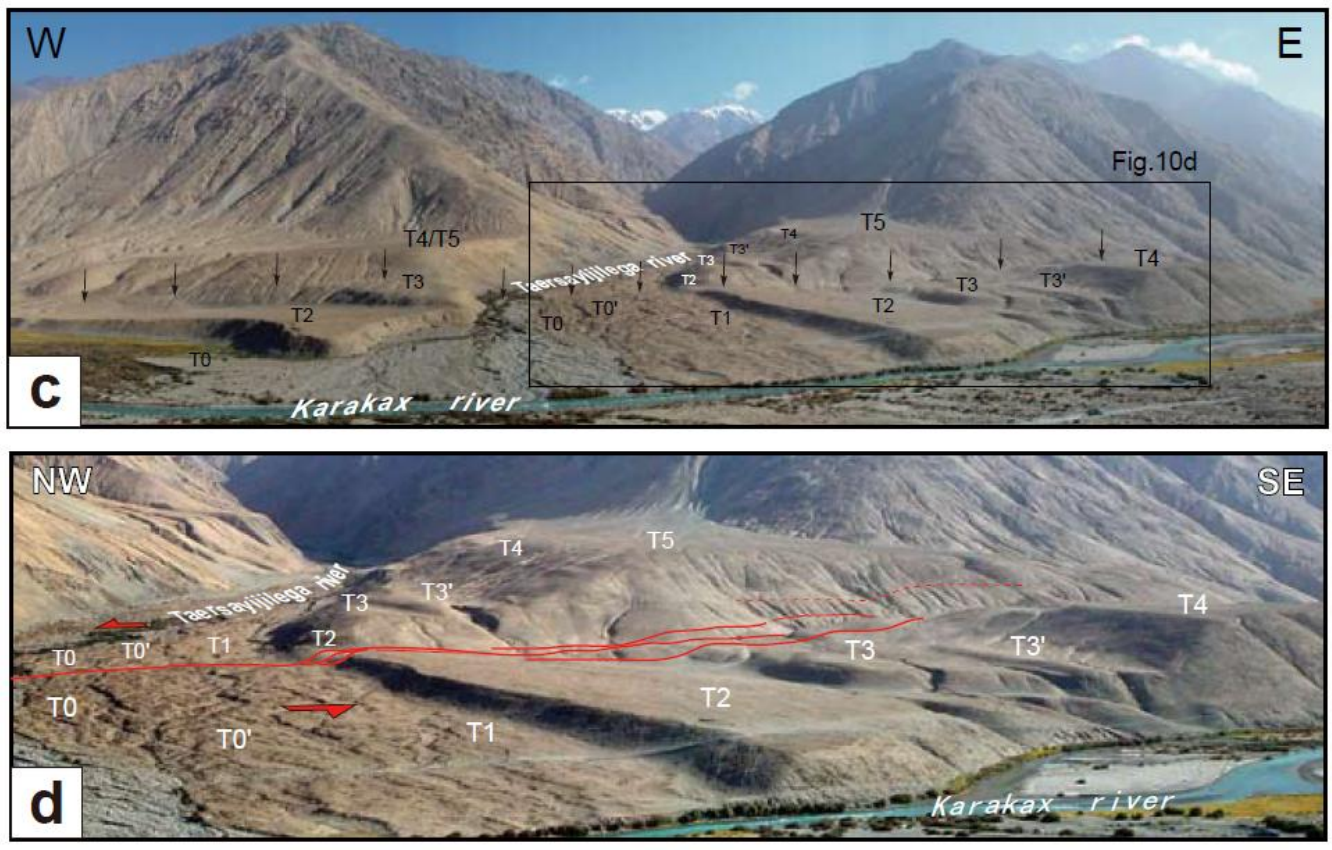

Li, H. et al.,-Figure 10c,d 


\section{a} Height $x 5$

(m) 120 120 [
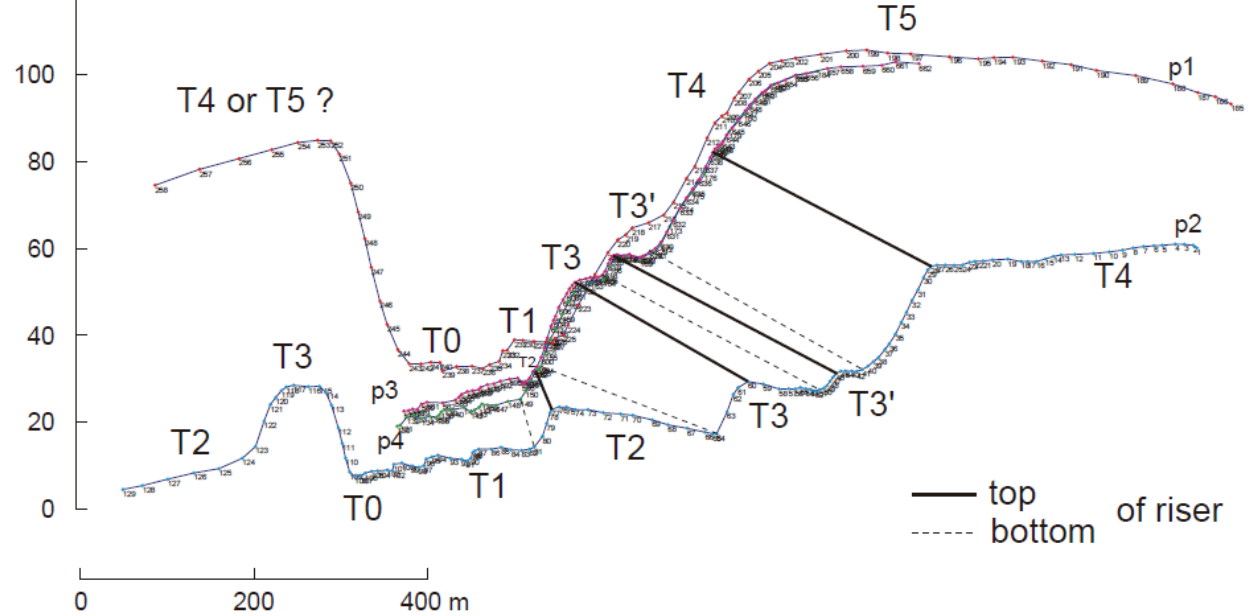

Projection N110E

E 
a
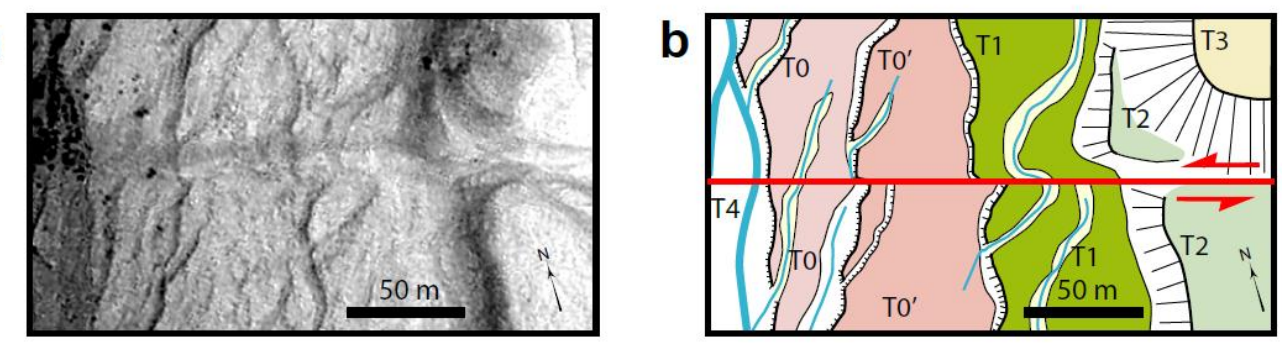

C
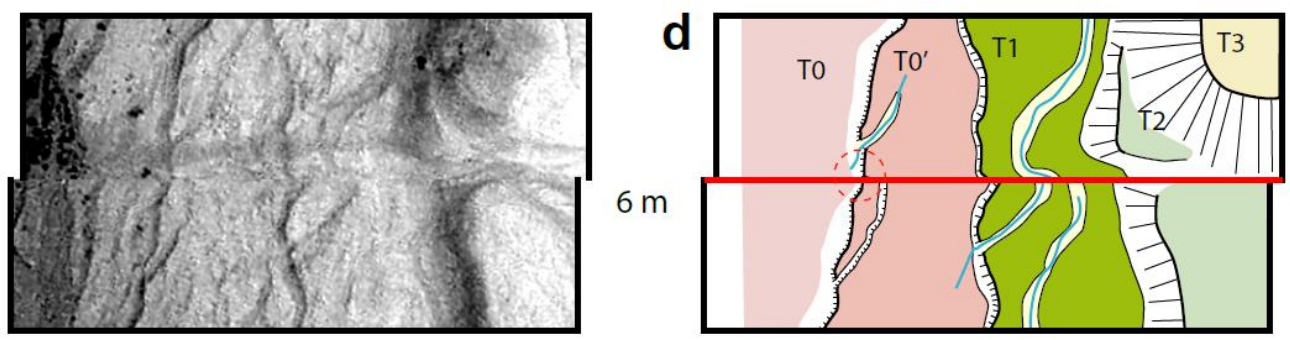

e
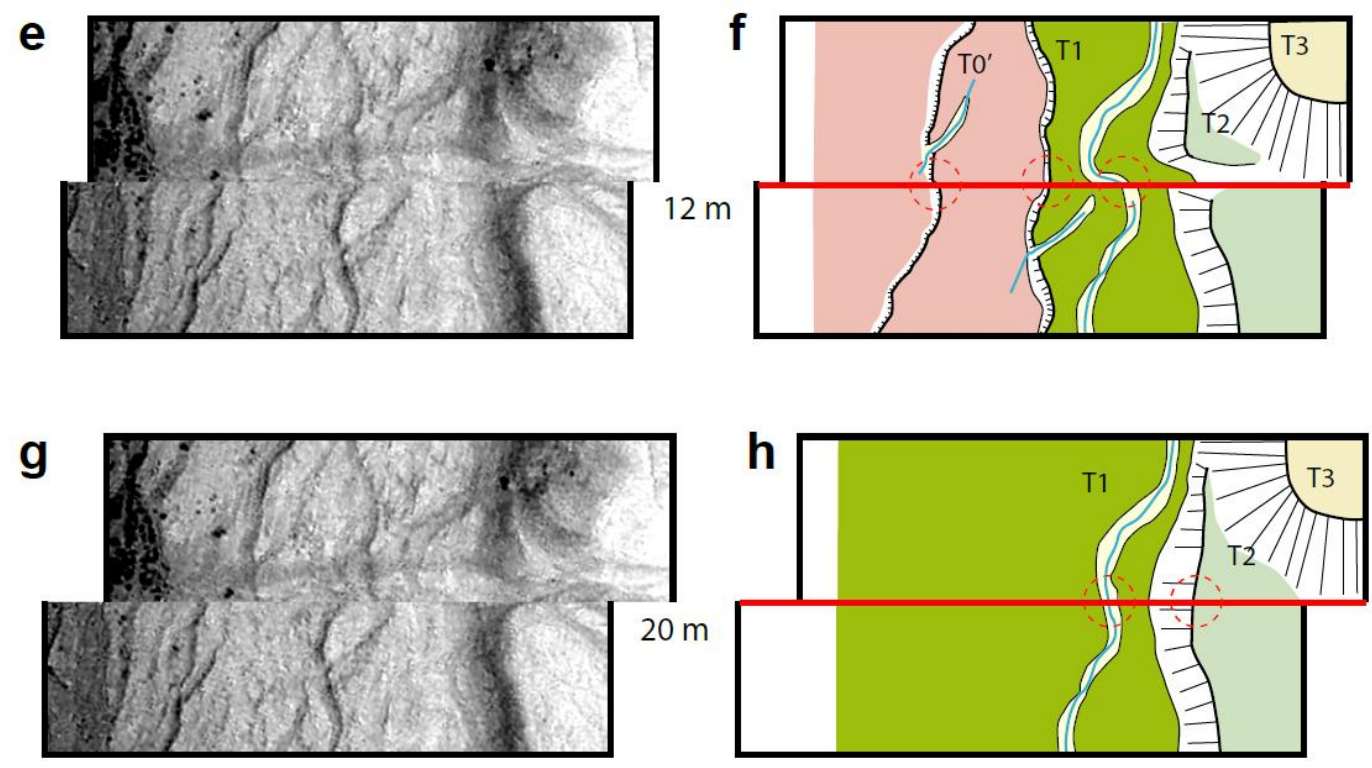

Li, H., et al. - Figure 12 

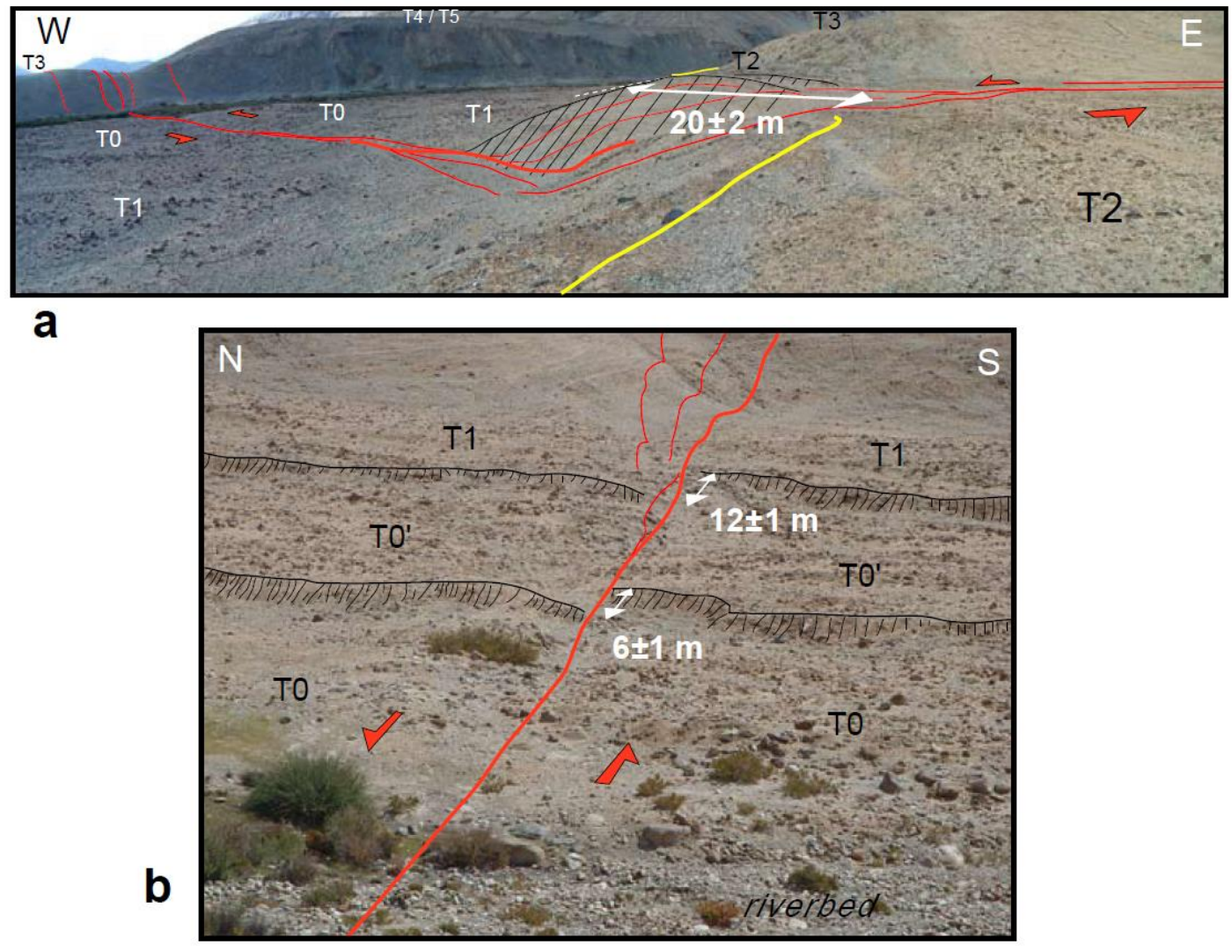

Li, H. et al.,-Figure 13 

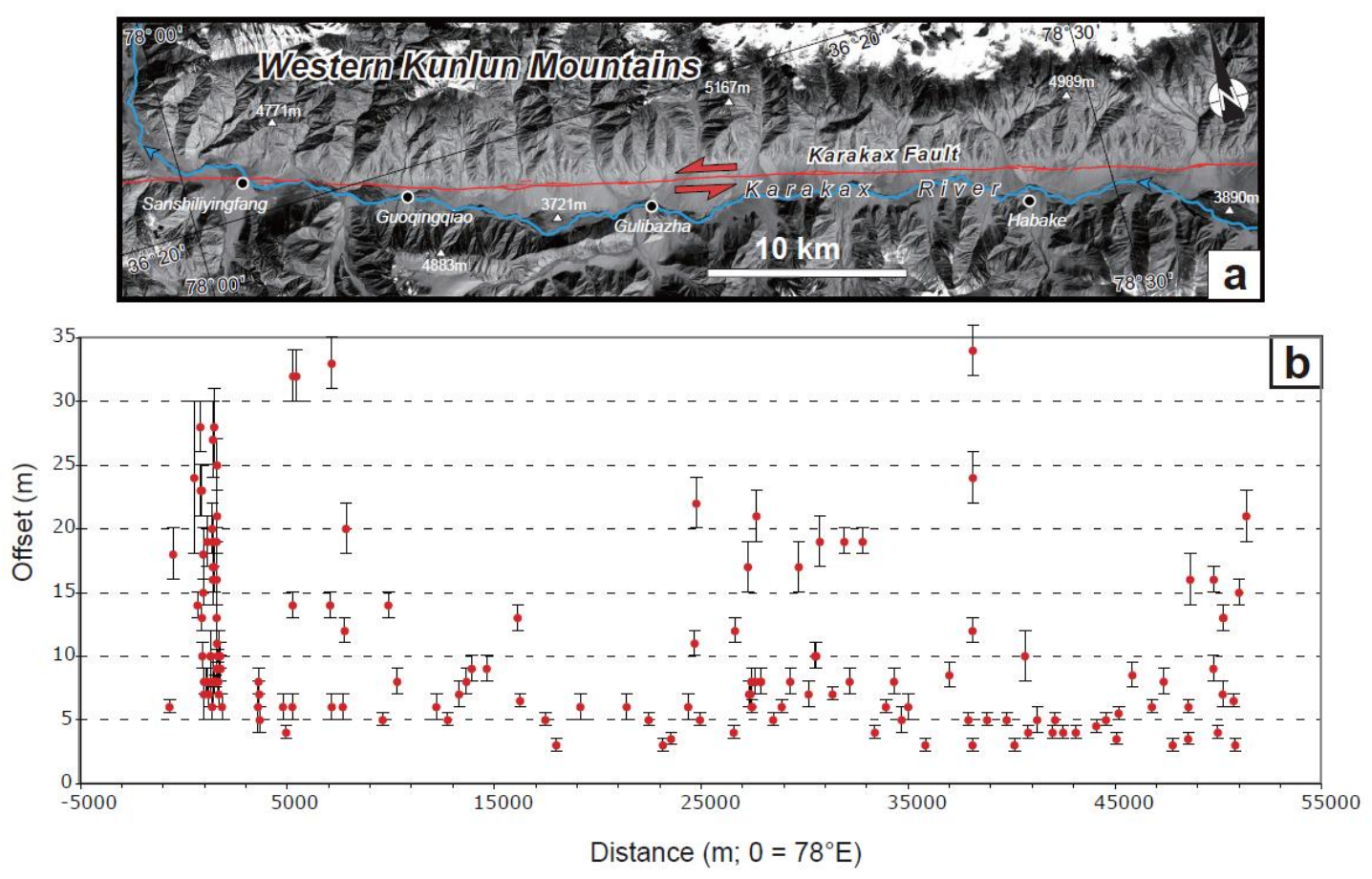

Li, H., et al. - Figure 14 


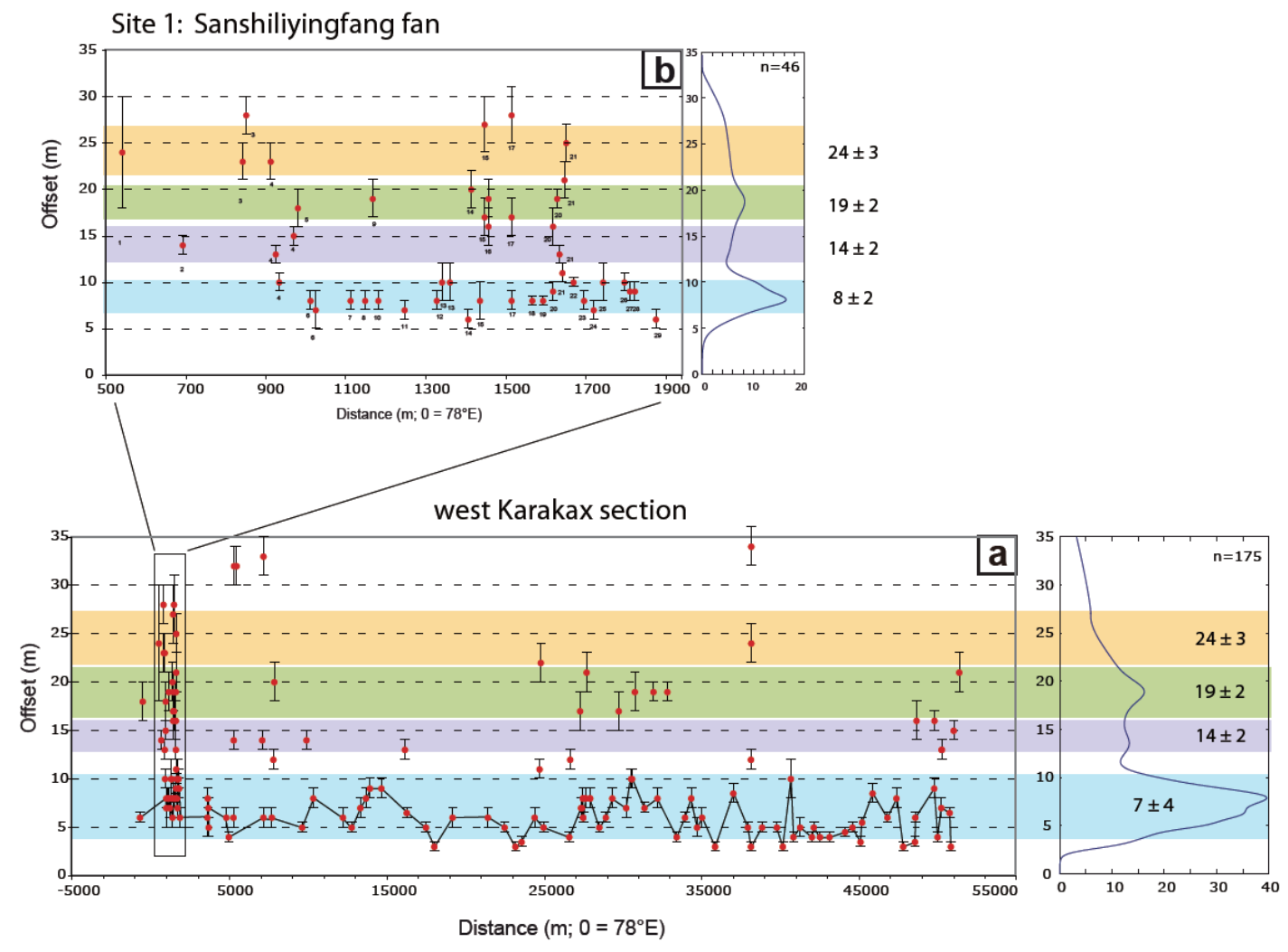

$\mathrm{Li}$, H. et al. - Figure 15 

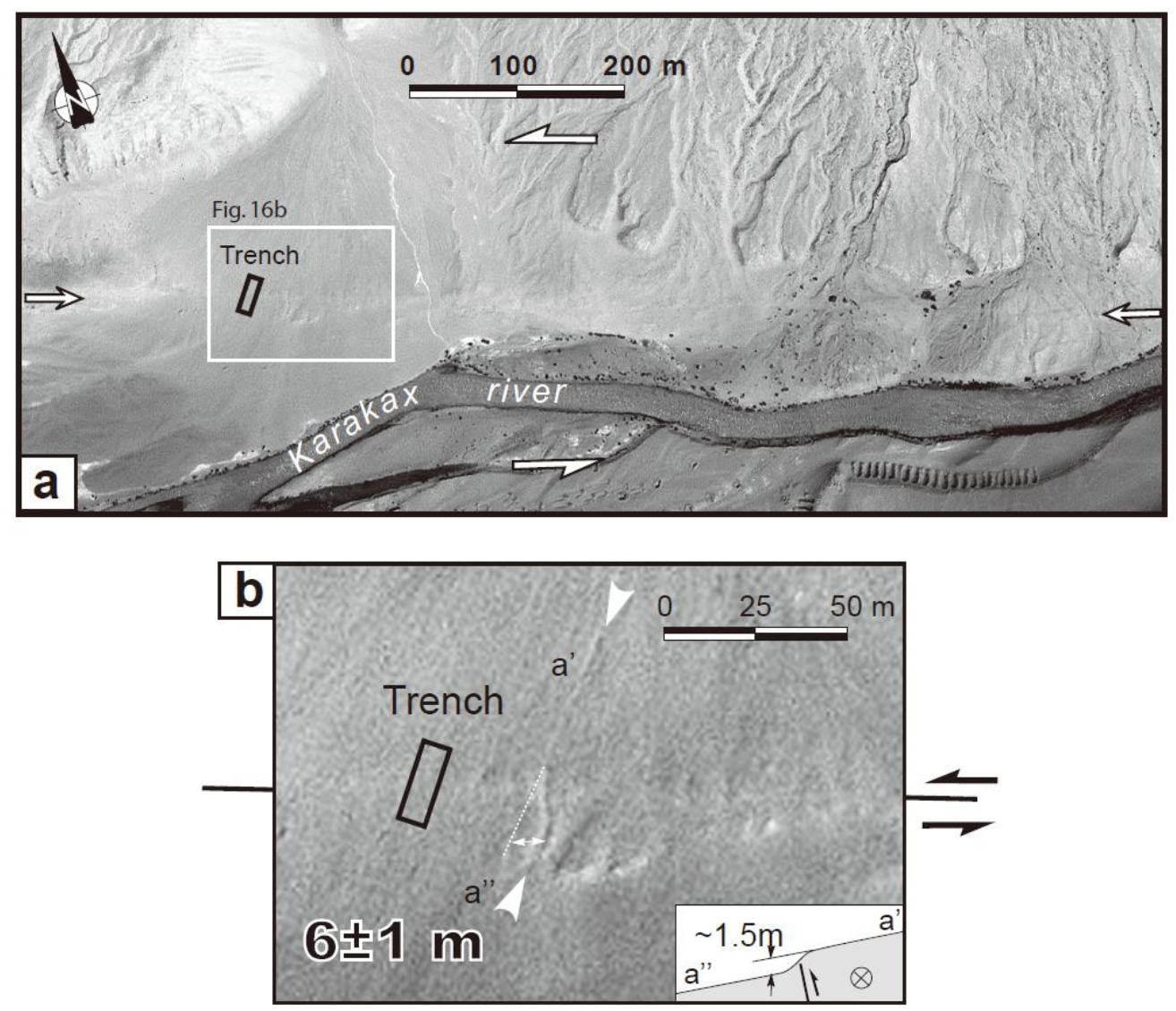

Li,H. et al. - Figure 16 

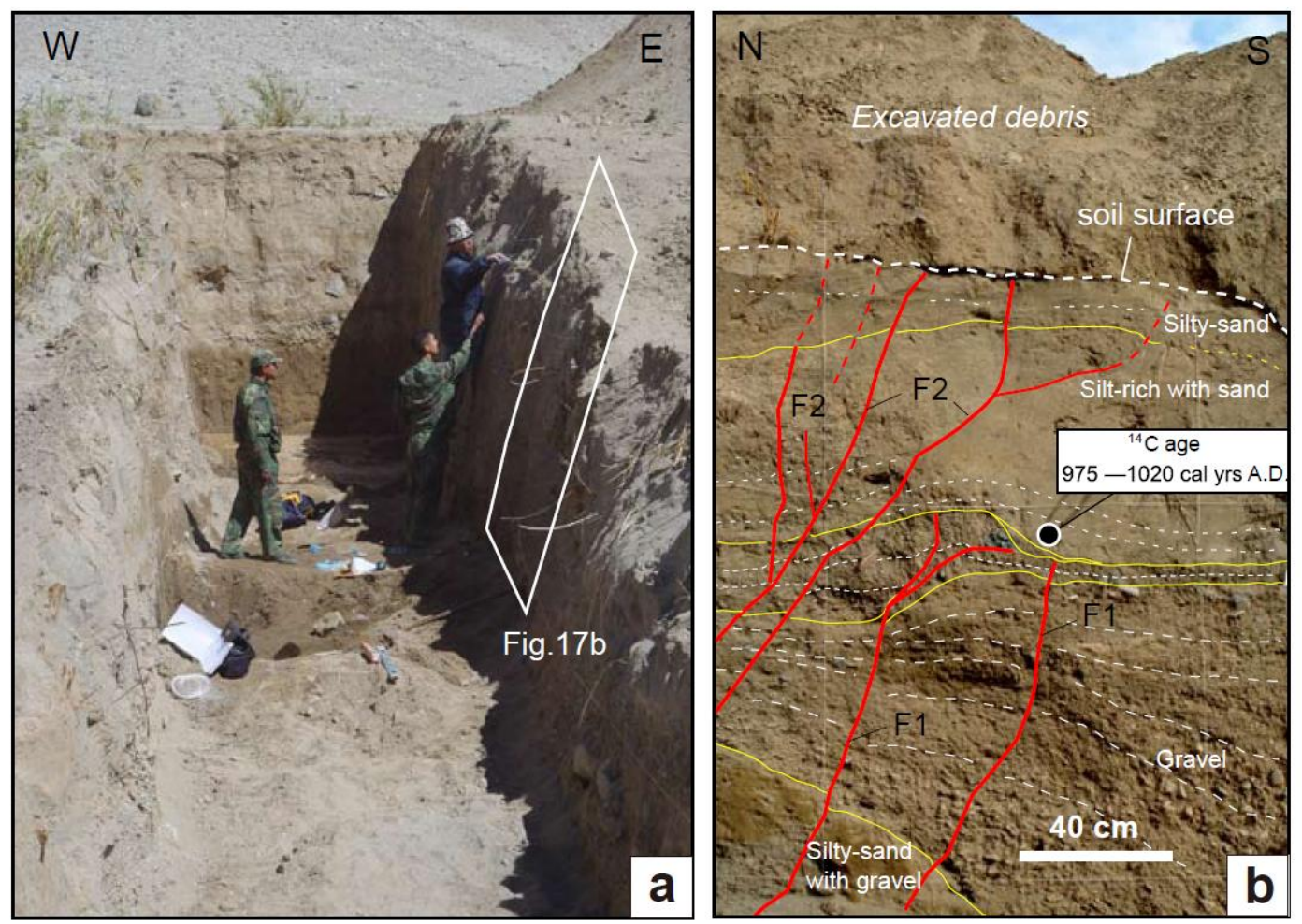

Li, H. et al. - Figure 17 
Graphical abstract

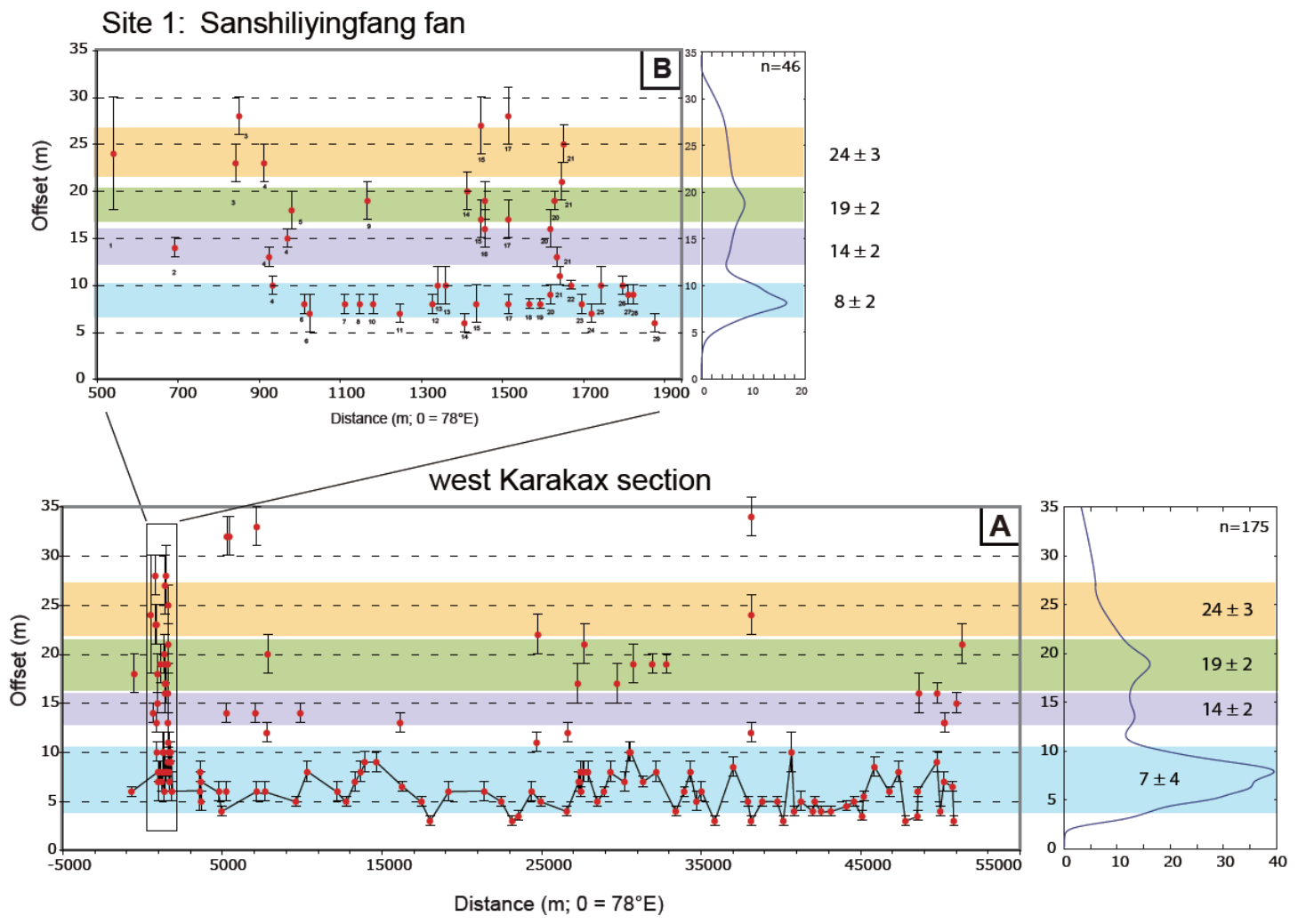




\section{Research Highlights}

The Karakax Fault co-seismic surface ruptures are visible for $\sim 100 \mathrm{~km}$ with left-lateral strike-slip movement. The $\sim 6 \mathrm{~m}$ characteristic offsets of the newly formed landforms are the maximal co-seismic offset of the most recent large earthquake. Recurrence interval for Mw7.4-7.6 earthquakes is $\sim 900$ years in this area. 